Article

\title{
HyCHEED System for Maintaining Stable Temperature Control during Preclinical Irreversible Electroporation Experiments at Clinically Relevant Temperature and Pulse Settings
}

\author{
Pierre Agnass 1,2,3 , Hans M. Rodermond ${ }^{1,3,4}$, Remko Zweije ${ }^{1}$, Jan Sijbrands ${ }^{1}$, \\ Jantien A. Vogel ${ }^{5}{ }^{(0}$, Krijn P. van Lienden $\left.{ }^{6}{ }^{(}\right)$, Thomas M. van Gulik ${ }^{2}$, Eran van Veldhuisen ${ }^{2}{ }^{(}$, \\ Nicolaas A. P. Franken ${ }^{1,3,4}\left(\mathbb{D}\right.$, Arlene L. Oei ${ }^{1,3,4} \mathbb{D}$, H. Petra Kok ${ }^{1,+} \mathbb{D}$, Marc G. Besselink ${ }^{2,+}(\mathbb{D}$ \\ and Johannes Crezee ${ }^{1, *,+}(\mathbb{D})$ \\ 1 Department of Radiation Oncology, Cancer Center Amsterdam, Amsterdam UMC, \\ University of Amsterdam, 1105 AZ Amsterdam, The Netherlands; p.agnass@amsterdamumc.nl (P.A.); \\ h.rodermond@amsterdamumc.nl (H.M.R.); r.zweije@amsterdamumc.nl (R.Z.); \\ j.sijbrands@amsterdamumc.nl (J.S.); n.a.franken@amsterdamumc.nl (N.A.P.F.); \\ a.1.oei@amsterdamumc.nl (A.L.O.); h.p.kok@amsterdamumc.nl (H.P.K.) \\ 2 Department of Surgery, Cancer Center Amsterdam, Amsterdam UMC, University of Amsterdam, \\ 1105 AZ Amsterdam, The Netherlands; t.m.vangulik@amsterdamumc.nl (T.M.v.G.); \\ e.vanveldhuisen@amsterdamumc.nl (E.v.V.); m.g.besselink@amsterdamumc.nl (M.G.B.) \\ 3 Laboratory of Experimental Oncology and Radiobiology, Cancer Center Amsterdam, Amsterdam UMC, \\ University of Amsterdam, 1105 AZ Amsterdam, The Netherlands \\ 4 Center for Experimental Molecular Medicine, Cancer Center Amsterdam, Amsterdam UMC, \\ University of Amsterdam, 1105 AZ Amsterdam, The Netherlands \\ 5 Department of Gastroenterology \& Hepatology, Amsterdam Gastroenterology and Metabolism, \\ Amsterdam UMC, University of Amsterdam, 1105 AZ Amsterdam, The Netherlands; \\ j.a.vogel@amsterdamumc.nl \\ 6 Department of Radiology, Cancer Center Amsterdam, Amsterdam UMC, University of Amsterdam, \\ 1105 AZ Amsterdam, The Netherlands; k.p.vanlienden@amsterdamumc.nl \\ * Correspondence: h.crezee@amsterdamumc.nl; Tel.: +31-20-566-4231 \\ + These authors contributed equally to this work.
}

Received: 15 September 2020; Accepted: 28 October 2020; Published: 31 October 2020

\begin{abstract}
Electric permeabilization of cell membranes is the main mechanism of irreversible electroporation (IRE), an ablation technique for treatment of unresectable cancers, but the pulses also induce a significant temperature increase in the treated volume. To investigate the therapeutically thermal contribution, a preclinical setup is required to apply IRE at desired temperatures while maintaining stable temperatures. This study's aim was to develop and test an electroporation device capable of maintaining a pre-specified stable and spatially homogeneous temperatures and electric field in a tumor cell suspension for several clinical-IRE-settings. A hydraulically controllable heat exchange electroporation device (HyCHEED) was developed and validated at $37^{\circ} \mathrm{C}$ and $46^{\circ} \mathrm{C}$. Through plate electrodes, HyCHEED achieved both a homogeneous electric field and homogenous-stable temperatures; IRE heat was removed through hydraulic cooling. IRE was applied to $300 \mu \mathrm{L}$ of pancreatic carcinoma cell suspension (Mia PaCa-2), after which cell viability and specific conductivity were determined. HyCHEED maintained stable temperatures within $\pm 1.5^{\circ} \mathrm{C}$ with respect to the target temperature for multiple IRE-settings at the selected temperature levels. An increase of cell death and specific conductivity, including post-treatment, was found to depend on electric-field strength and temperature. HyCHEED is capable of maintaining stable temperatures during IRE-experiments. This provides an excellent basis to assess the contribution of thermal effects to IRE and other bio-electromagnetic techniques.
\end{abstract}


Keywords: hydraulic-control-system; heating-system; cooling-system; electroporation; electromagnetics; hyperthermia

\section{Introduction}

Irreversible electroporation (IRE) is a relatively new focal ablation technique for the treatment of unresectable solid tumors at challenging anatomical sites including the liver, kidney, and pancreas [1-3]. IRE is a modality in which short but high-voltage pulses are applied between electrodes implanted in the target volume to cause nanopores in the cell membranes. The pore formation induces disturbances in the cell's homeostasis, with cell death as consequence through accidental and regulated cell death mechanisms, and causes an increase of the electrical specific conductivity in the bulk tissue due to improved solute mobility $[4,5]$.

Contrary to thermal ablation modalities, such as radiofrequency ablation, microwave ablation, and cryoablation, IRE is assumed to have the advantage of being less prone to local cooling by the heat-sink effect [6]; an effect that is known to hamper the successful treatment of thermal ablation modalities due to underdosage near large blood vessels in the ablation zone [7]. In addition, IRE preserves the vital structures (e.g., blood vessels, bile ducts) traversing the ablation zones, since fibrous and collagen structures are typically not affected by IRE [6].

Despite the fact that IRE was initially introduced as a non-thermal technique, the application of repetitive high-intensity electrical pulses in the target organs, inevitably leads to increased temperatures during ablation [8-11]. The produced thermal effects could have the potential to enhance the effectiveness of IRE treatment, since mild hyperthermia and thermal ablation are known to have therapeutic effects. Specifically, mild hyperthermic temperatures $\left(\mathrm{T} \leq 45^{\circ} \mathrm{C}\right)$ enhance the therapeutic effects of chemotherapy and radiotherapy, depending on the temperature and the duration of heating, i.e., the thermal dose $[3,12-16]$. These enhancements are achieved through a variety of molecular and physiological mechanisms, including inhibition of DNA damage repair for $\mathrm{T}>\sim 41{ }^{\circ} \mathrm{C}$, increase of blood flow and reoxygenation for $39^{\circ} \mathrm{C}<\mathrm{T}<44^{\circ} \mathrm{C}$, decrease of tumor $\mathrm{pH}$, and stimulation of the immune response [15,17-19]. Direct cell kill will occur at ablative temperatures, e.g., for short duration exposure to $\mathrm{T} \geq 50^{\circ} \mathrm{C}[8,20,21]$. The temperature increase during traditional mild hyperthermia and thermal ablation is produced using invasive or external techniques, such as electromagnetic, capacitive, conductive heating, or focused ultrasound techniques [3,22-26].

During IRE, the produced thermal effects at mild hyperthermic temperature levels have the potential to enhance the irreversible permeabilization effects (IPE) by reducing the resistance of the tissue and the electric-field threshold for nanopore formation $\left(\mathrm{E}_{\mathrm{IRE}(\mathrm{th})}\right)$ [27]. We chose IPE instead of IRE effect to distinguish between only the permeabilization effect, and the permeabilization and the thermal effects jointly produced by IRE. For higher temperature levels $\left(\mathrm{T} \geq 50^{\circ} \mathrm{C}[8,20,21]\right)$, even direct thermal damage could occur, which can result in thermal ablation, especially in the vicinity of the needle electrodes [8-11]. However, it remains unclear to what extent the thermal effects of IRE contribute to tissue ablation. A better understanding of this contribution can help to establish IRE settings that maximize the ablative tumor effect.

Establishing the contribution of thermal effects requires performing pre-clinical IRE experiments while maintaining a well-defined, stable temperature. The latter is challenging, as the very process of IRE can cause an unpredictable temperature rise [8-11,20], which needs to be dealt with to achieve stable experimental conditions. Several studies developed setups that aimed at maintaining the temperature of the target volume at a specific target temperature $\left(\mathrm{T}_{\text {target }}\left[{ }^{\circ} \mathrm{C}\right]\right)$ during IRE $[27,28]$. For example, Edelblute et al. attempted to heat and maintain the temperature of their target volumes at a desired temperature using a heat block or time-modulated fiber optic laser [27]. In the case of Zhang et al., the desired temperatures were achieved by preheating the target using a radiofrequency ablation technique [28]. Overall, temperature maintenance in the target volume was achieved due 
to the controlled heat exchange between the target volume and ambient environment that resulted in temperature fluctuations of $2-5^{\circ} \mathrm{C}$ with respect to the $T_{\text {target }}$. However, the needle electrodes generally utilized in IRE studies inevitably yield spatially heterogeneous electric-field and temperature distributions, with higher energy deposition close to the needles. To thoroughly investigate the influence and dose-effect relationships of both the electric-field and thermal distribution, it is important to maintain the electrical and thermal parameter levels spatially as homogeneously as possible for all the various temperature and pulse settings used, while maintaining the temperature variation as small as possible. This requires careful balancing of the heat exchange between the target volume and the ambient environment for various pulse settings. This is challenging, since the temperature increase not only varies as function of the pulse settings, but also as function of the $T_{\text {target }}$ due to the increase in the electrical and thermal conductivity of the target tissue as a function of both pulse settings and $\mathrm{T}_{\text {target }}[20]$.

Therefore, the main objective of this paper is to present, demonstrate, and validate a novel temperature-controlled electroporation device capable of maintaining a pre-specified stable temperature level in a target volume (TV) with small temperature variation while performing IRE for several different fixed clinically relevant IRE settings in vitro in between plate electrodes. The second objective is to illustrate how this device can be used to determine the influence of IPE and thermal effects on (1) the cell viability in vitro and (2) the electrical specific conductivity $\left(\sigma\left[\mathrm{S} \cdot \mathrm{m}^{-1}\right]\right)$ during and after IRE treatment.

\section{Materials and Methods}

A hydraulically controllable heat exchange electroporation device (HyCHEED) was developed to maintain a stable temperature level in a target volume (TV) during electroporation by removing the heat generated by the electric pulses. The main challenge is thus to create a balance between heat generation due to electric pulses and heat removal by HyCHEED. The sophisticated control mechanism developed for this purpose is schematically illustrated in Figure 1 and will be further explained in the next paragraphs. Specifically, the mechanical structure and the mathematical concept of HyCHEED will be explained in Section 2.1. Materials and Instruments and Appendix A-Mathematical Description of Stable Temperature Control in Treated Volume. 


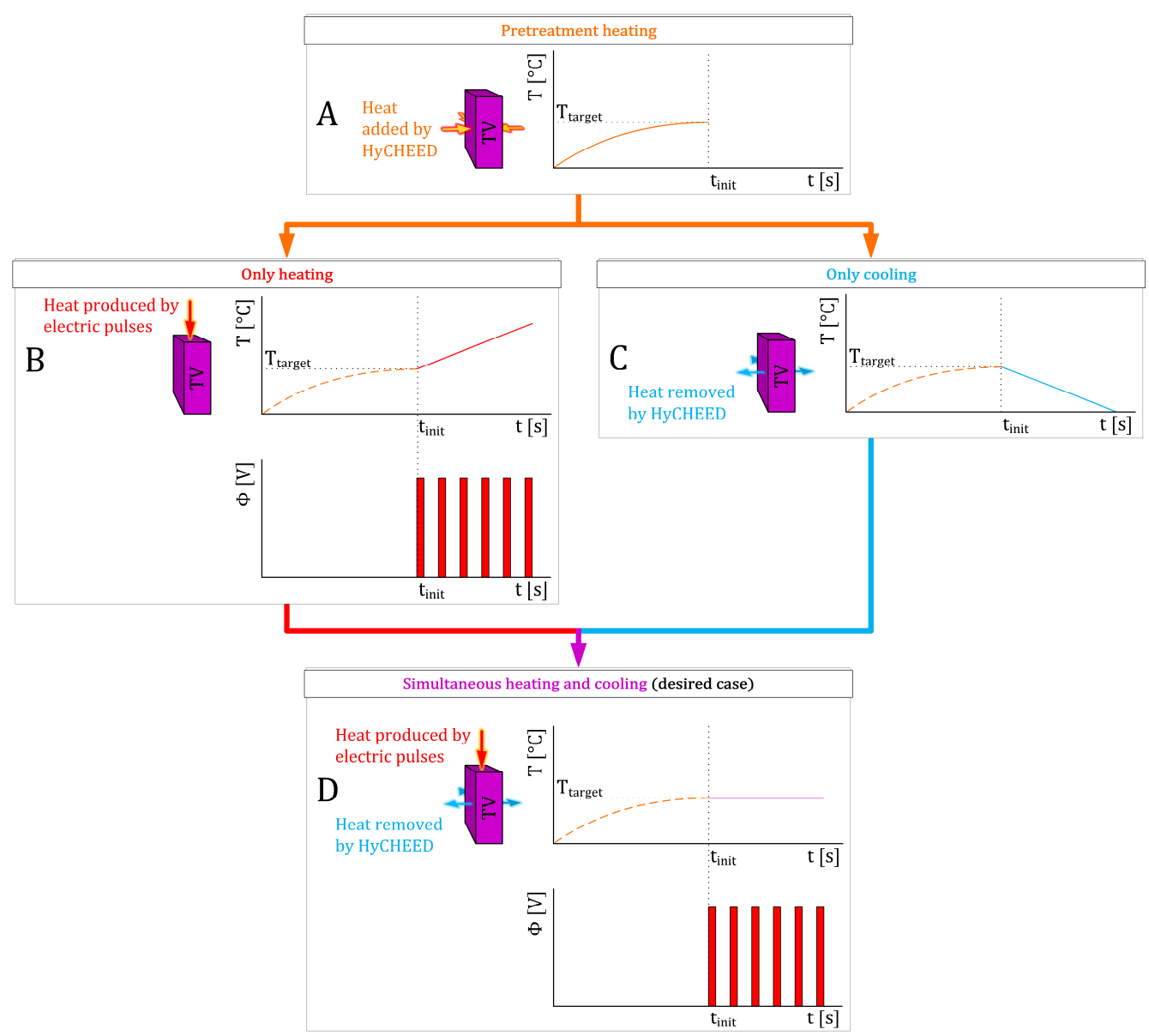

Figure 1. Schematic illustration of the temperature control mechanism of the hydraulically controllable heat exchange electroporation device (HyCHEED). (A) The left side illustrates a target volume (TV) represented by a purple cuboid that is heated up by HyCHEED up to the target temperature ( $\mathrm{T}_{\text {target }}$ $\left.\left[{ }^{\circ} \mathrm{C}\right]\right)$ prior to the initial time ( $\left.\mathrm{t}_{\text {init }}[\mathrm{s}]\right)$ at which IRE starts; the heat is represented by orange arrows. The right side shows the temperature $\left(\mathrm{T}\left[{ }^{\circ} \mathrm{C}\right]\right)$ of the TV as a function of time $(\mathrm{t}[\mathrm{s}])$. Please note that the black dotted lines represent $T_{\text {target }}$ and $t_{\text {init }}$. After achieving $T_{\text {target }}$ for $(\mathbf{B}-\mathbf{D})$, three situations were presented: Situation 1 (B) illustrates the TV in which the heat is generated at $t_{\text {init }}$ due to a series of electric pulses with voltage $(\Phi[V])$ in the TV when neglecting any cooling effects; the produced heat due to the electric pulses is represented by a red arrow. Situation 2 (C) illustrates the TV from which heat is removed by HyCHEED when neglecting heating by the electric pulses; the heat removal is represented by blue arrows. Situation 3 (D; the desired case) illustrates the TV in which a balance is achieved between heat generation due to electric pulses and heat removal by HyCHEED.

\subsection{Materials and Instruments}

HyCHEED consists of (1) a hydraulic unit through which demineralized water (demi-water) flows for controlled heating/cooling of the TV, (2) an electrical unit for application of IRE to the TV, and (3) a control unit that controls the heat exchange in the TV during IRE to achieve and maintain the pre-specified temperature level. In this paper a TV of $\sim 300 \mu \mathrm{L}$ of cell suspension was treated.

\subsubsection{Hydraulic Unit}

The hydraulic circuit pumped demi-water through temperature-controlled containers to the target holder (T-holder; hyperlink to see Section 2.2.). Two water containers were used to control the demi-water temperature to create stable temperature control in the TV under dynamic conditions during IRE-one container at high temperature (H-container) for increasing the temperature in TV and the other at temperature lower than $\mathrm{T}_{\text {target }}$ (C-container) for achieving cooling when needed. Both containers 
were filled with demi-water that heated up to appropriate temperature levels, depending on $\mathrm{T}_{\text {target }}$. For an example, see Table 1. Two peristaltic pumps (VPER-HF, FWT SYSTEMS SRLS, Rome, Italy) placed before the T-holder were used to circulate the demi-water at a stable flow rate inside the T-holder to control the temperature of the TV. See the red, light blue, and purple lines and shapes in Figure 2.

Table 1. Average temperatures of the demineralized water in the heating $(\mathrm{H})$ and cooling $(\mathrm{C})$ containers. These temperatures depend on the target temperature $\left(\mathrm{T}_{\text {target }}\left[{ }^{\circ} \mathrm{C}\right]\right)$ and IRE settings. The temperatures of $\mathrm{H}$-containers were used for both $500 \mathrm{~V} \cdot \mathrm{cm}^{-1}$ and $1250 \mathrm{~V} \cdot \mathrm{cm}^{-1}$, while temperatures of C-containers were only used for $1250 \mathrm{~V} \cdot \mathrm{cm}^{-1}$.

\begin{tabular}{ccc}
\hline $\mathbf{T}_{\text {target }}\left[{ }^{\circ} \mathbf{C}\right]$ & Temperature of $\mathbf{H}$-Container $\left[{ }^{\circ} \mathbf{C}\right]$ & Temperature of C-Container $\left[{ }^{\circ} \mathbf{C}\right]$ \\
\hline 37 & 37.5 & 32.4 \\
$\mathbf{4 6}$ & 46.1 & 44.2 \\
\hline
\end{tabular}

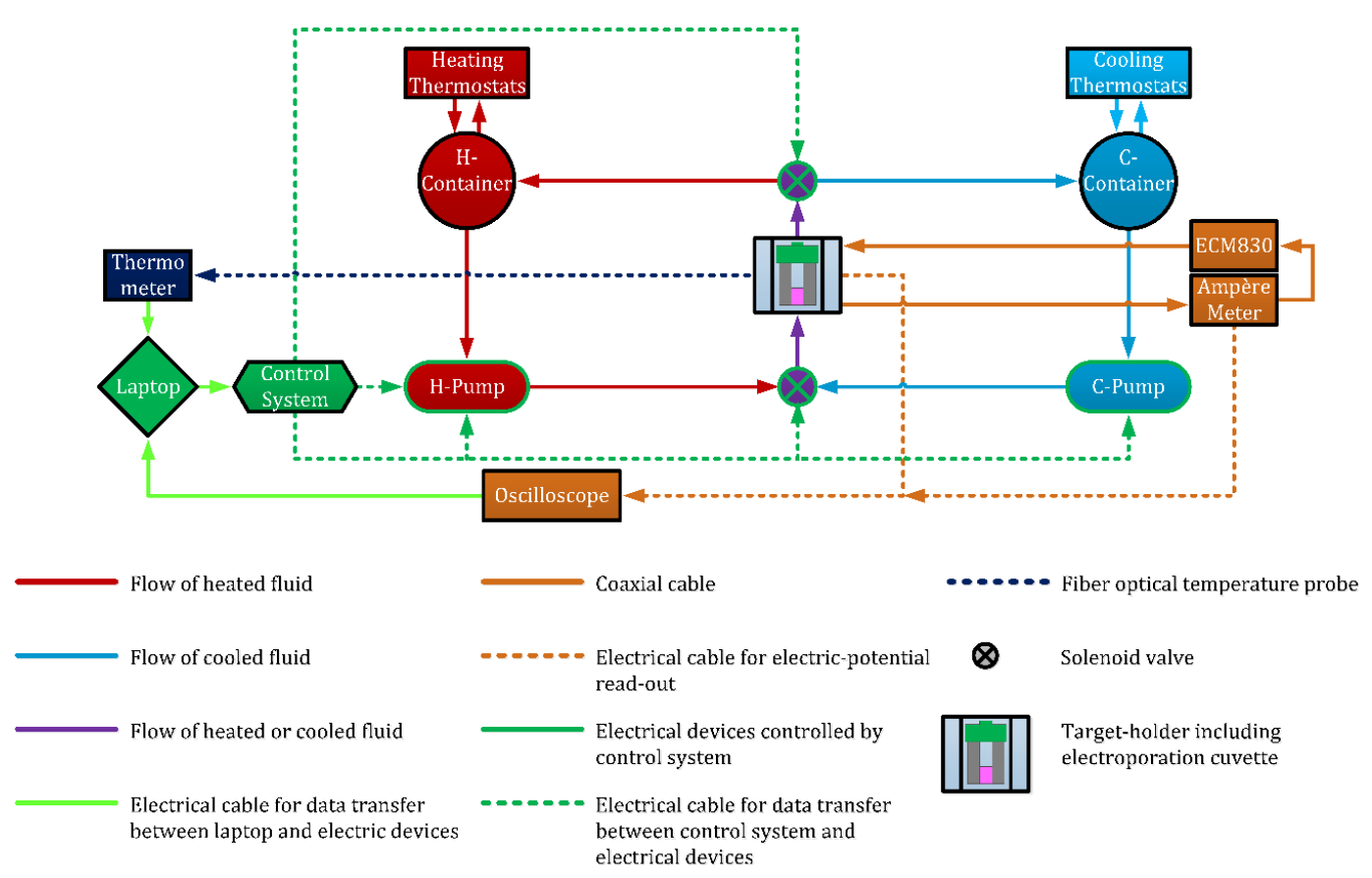

Figure 2. Overview of the controlled hydraulic circuit. The colors red, light blue, and purple represent different parts of the hydraulic unit, the color light brown represents the electric unit, the colors green and light green represent the control unit, and the color dark blue represents fiber optical thermometer. Please note that parts of the hydraulic unit with green lines are controlled by the control unit. Also note that the letters $\mathrm{H}$ and $\mathrm{C}$ are abbreviations of the words heating and cooling.

\subsubsection{Electric Unit}

The cell suspension was treated using an electroporation cuvette (WB 1-4120, Westburg, Leusden, The Netherlands). The cuvette includes two plate electrodes made of aluminum with an inter-electrode distance of $2 \mathrm{~mm}$ between which the cell suspension is included. Specifically, the cuvette was placed inside the T-holder to control the temperature of the cell suspension. In the T-holder, the electrodes of the cuvette contact thin copper tapes that are connected to the pulsing circuit. More details about the architecture of the T-holder including the electrode connections are described in hyperlink to Section 2.2. The electric pulsing circuit consists of the pulse generator ECM ${ }^{\circledR} 830$ (BTX-Harvard Apparatus, Holliston, MA, USA) in series with an electrical resistor of $0.1 \Omega$ for the measurement of electric current and PicoScope3206 (Pico Technology, Saint Neots, UK) to record the electric voltages across the cuvette and the electrical resistor of $0.1 \Omega$. See the light brown blocks and lines in Figure 2. 


\subsubsection{Control Unit}

Two solenoids valves (Type 0124, Christian Bürkert GmbH \& Co. KG, Ingelfingen, Germany) were used to regulate and mix the flow of the heated and the cooled demi-water. A control system was built to control the water flow and valve settings and thereby the temperature of the cell suspension by switching between the solenoids valves and the pumps. In Figure 2, the control unit is indicated as (light) green lines and shapes.

\subsection{Target-Holder Architecture}

The T-holder architecture consists of (1) a small container and a water bolus to obtain and maintain $\mathrm{T}_{\text {target }}$ in the TV during IRE and (2) an electrical part through which IRE was applied to the TV (Figure 3). The container was designed using the open-source parametric 3D computer-aided design modeler FreeCAD V0.16 and 3D printed using polylactic acid (PLA) fiber. Furthermore, the water bolus wall consists of $0.2 \mathrm{~mm}$ polyvinyl chloride (PVC) film type claris (Walvis Products, Franeker, The Netherlands). The bolus was glued to the side of the container in which an electroporation cuvette was positioned. For the application of IRE, two copper-film tapes with a width of $10 \mathrm{~mm}$ were soldered to electrical wires that were connected to female banana connecters. The copper tapes were attached to the water bolus.

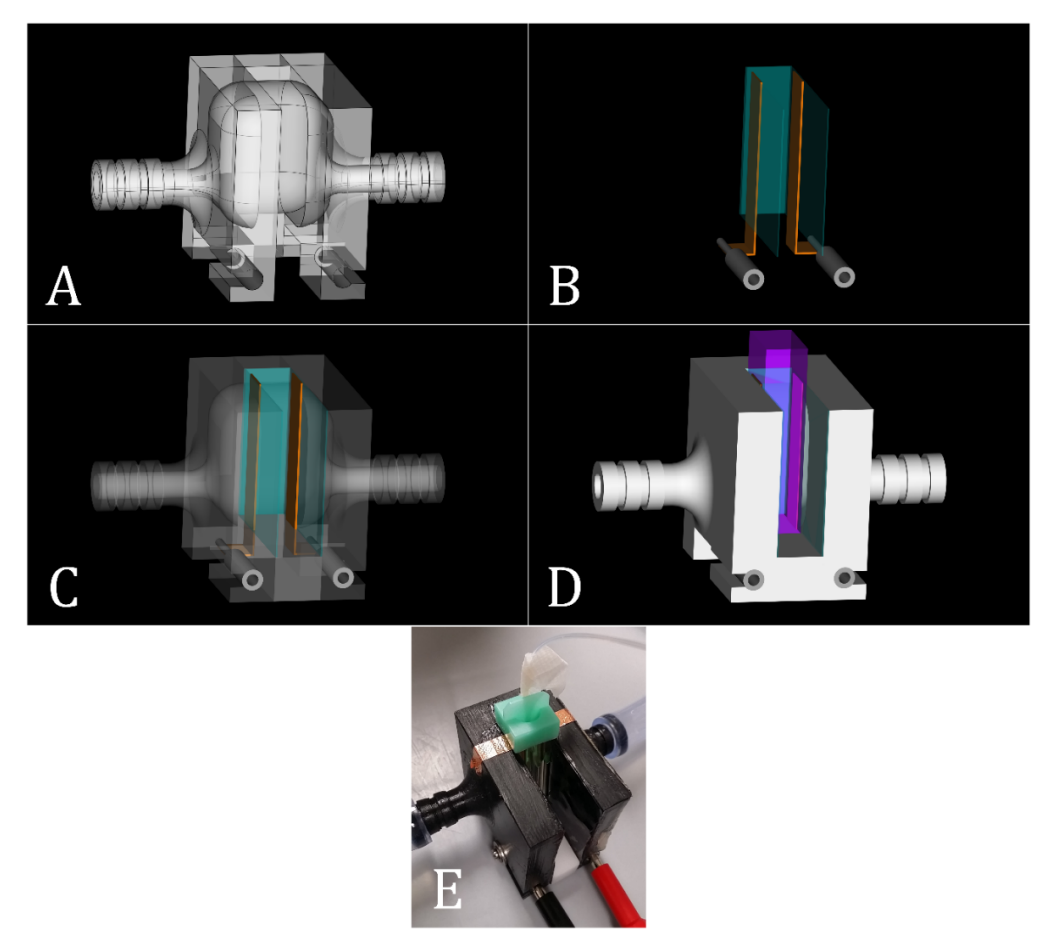

Figure 3. (A) A transparent version of the target holder (T-holder) with rounded edges and corners at the inside for optimal water flow. (B) Female banana connectors (color gray) connected to copper-film tapes (color brown; with width of $10 \mathrm{~mm}$ ) that were taped to the water bolus (PVC film; color turquoise). (C) Transparent T-holder combined with the electrodes and the water bolus from (B). In between the banana connectors, a PLA block was used as a stand support for the electroporation cuvette. (D) A complete T-holder model including an electroporation cuvette (color purple). Here, the cuvette can be slid from above or the front along the water bolus and the copper tapes. The electroporation cuvette includes two plate-electrodes with a $2 \mathrm{~mm}$ gap that is filled with cell suspension (cells in culture medium). These electrodes contact the copper tapes that are connected to the pulsing circuit for the application of IRE. (E) T-holder used during the experiments. The optical probe was inserted inside the catheter, with open ends, placed in the cap of the cuvette. To avoid probe motions, the catheter was pasted on the probe on one end using adhesive tape, after which the tape was disinfected. 


\subsection{Temperature Measurements}

Temperatures were measured using a single fiber optical temperature probe in the cell suspension (the TV) with a sample frequency of $1 \mathrm{~Hz}$. The temperature probe is located in between the electrodes in the middle and at the bottom of the cuvette. Furthermore, the fiber optical temperature setup consisted of a rack-mounted Lumiterm X5 OEM temperature board connected to Lumiterm X5-True fiber optical temperature probes with a diameter of $1 \mathrm{~mm}$ (IPITEK, Carlsbad, CA, USA). The temperature probes have a resolution of $0.05{ }^{\circ} \mathrm{C}$ with an accuracy of $0.2^{\circ} \mathrm{C}$ and are not affected by the presence of an electric field. Around the fiber optical temperature probe, a slight distortion can occur in the electric-field distribution. However, since the diameter of the optical probe $(1 \mathrm{~mm})$ is relatively small with respect to the width of the cuvette $(10 \mathrm{~mm})$, the electric-field distribution can be assumed to be homogeneously distributed in the remaining effective width $(9 \mathrm{~mm})$ of the cell suspension. Nevertheless, for future applications, it would be possible to remove the optical temperature probe just before the application of IRE and instantaneously reinsert it at the end of the treatment. This would avoid any distortion of the electric field-distribution. Please note that the main objective of this study was to present and validate an experimental set-up capable of maintaining stable temperatures "during" preclinical IRE experiments, and therefore, we chose to keep the optical temperature probe inside the target volume for the specific purpose of demonstrating the proof of principle. This does imply that, in the actual experimental use, there is no need for having a temperature probe inside the cuvette during the actual electroporation itself and that the optical temperature probe can be removed just before the application of IRE and instantaneously reinserted at the end of the treatment.

\subsection{Cell Line and Cell Culture}

In view of the relevance of the clinical application of IRE in pancreatic cancers $[29,30]$, a pancreatic carcinoma cell line was selected for the validation of HyCHEED. The human pancreatic carcinoma Mia PaCa-2 (ATCC, Manassas, VA, USA) was grown in high glucose in Dulbecco's Modified Eagle Medium (Life Technologies, Carlsbad, CA, USA) that was supplemented with 10\% heat-inactivated fetal bovine serum (Gibco, Rockville, MD, USA) and $2 \mathrm{mmol} \cdot \mathrm{L}^{-1}$ glutamine (Gibco, Rockville, MD, USA). The cells were cultured in a $37^{\circ} \mathrm{C}$ incubator with humidified air supplemented with $5 \% \mathrm{CO}_{2}$. After reaching a confluence of $90 \%$, the cells were harvested via trypsinization (5 time diluted $0.5 \%$ Trypsin-EDTA, Gibco, Rockville, MD, USA) and suspended in the culture medium at a concentration of $0.98 \times 10^{6}-1.40 \times 10^{6}$ cells $\cdot \mathrm{mL}^{-1}$. The cell concentrations were determined using Trypan blue stain assay and an automated bright-field cell counter (LUNA ${ }^{\mathrm{TM}}$ Automated Cell Counter, Aligned Genetics, Inc., Anyang-si, Korea). The protocol to determine the cell concentrations is described in Section 2.6.2. Please note that for the experiments in this study the culture medium was used in the cell suspension during the treatments. In Section 2.6 methods are discussed for the evaluation of the cells treated by HyCHEED.

\subsection{Validation of HyCHEED}

\subsubsection{Choice and Evaluation of Pulse Settings and Target Temperatures}

The main aim of this article is to validate HyCHEED and to show its capability to operate with stable temperatures at different temperature levels. Therefore, without loss of generality two temperature values $37^{\circ} \mathrm{C}$ and $46^{\circ} \mathrm{C}$ were selected as $\mathrm{T}_{\text {target, }}$, which represent the normothermic physiological $\left(37^{\circ} \mathrm{C}\right)$ and hyperthermic temperature $\left(46^{\circ} \mathrm{C}\right)$ that can develop during an IRE-treatment [20]. The reasons for choosing $46^{\circ} \mathrm{C}$ are:

- a significant temperature difference compared to $37^{\circ} \mathrm{C}$, allowing us to demonstrate the capability of HyCHEED to operate at different temperatures;

- the likelihood of occurrence of $46^{\circ} \mathrm{C}$ during typical IRE treatment [9-11]; 
- the limited direct cell death after brief exposure $(\sim 2-3 \mathrm{~min})$ to $46^{\circ} \mathrm{C}$ to allow the determination of the influence of the combined effects of IPE and temperature on both cell viability and specific conductivity $[3,20,21]$.

At these temperatures, clinical IRE setting was applied to the TV consisting of a series of 90 pulses with a pulse duration of $90 \mu \mathrm{s}$ and an electric-field strength $\left(\mathrm{E}\left[\mathrm{V} \cdot \mathrm{cm}^{-1}\right]\right)$ of $1250 \mathrm{~V} \cdot \mathrm{cm}^{-1}[11,29,31]$. To examine the influence of the $T_{\text {target }}$ on the TV during IRE, additional IRE setting was selected in which the $\mathrm{E}$ value was reduced to $500 \mathrm{~V} \cdot \mathrm{cm}^{-1}$ while maintaining the pulse duration and number.

Furthermore, the electric current and voltage of the first and the 90th pulses were evaluated to determine the capability of HyCHEED of producing typical electroporation pulses. The stability of the temperatures in the TV was assessed by calculating the mean and the standard deviation (SD) of the TV temperatures over the treatment time.

\subsubsection{Operation Protocol of HyCHEED}

This section describes the operation protocol of HyCHEED in vitro, as illustrated in Figure 4. Depending on the pre-specified $\mathrm{T}_{\text {target }}$ and electroporation settings, the demi-water in the containers was heated to temperatures specified in Table $1\left(t_{0} \rightarrow t_{1}\right.$ in Figure 4). After obtaining the desired temperatures in the containers, $\sim 300 \mu \mathrm{L}$ of cell suspension was pipetted in the cuvette. To repeat, the culture medium was used in the cell suspension. Next, the fiber optical temperature probe was disinfected and inserted in the cell suspension in the cuvette inside the fume hood. Subsequently, the cuvette was slid along the water bolus, and copper tapes from above and the H-pump was turned on $\left(t_{1} \rightarrow t_{2}\right.$ in Figure 4). After obtaining $\mathrm{T}\left[{ }^{\circ} \mathrm{C}\right] \geq \mathrm{T}_{\text {target }}-1.5^{\circ} \mathrm{C}$ in the cell suspension $\left(t_{2} \rightarrow t_{3}\right.$ in Figure 4), electroporation treatment was performed ( $t_{3} \rightarrow t_{4}$ in Figure 4$)$. The reason for starting at $\mathrm{T}_{\text {target }}-1.5^{\circ} \mathrm{C}$ was to suppress the expected temperature increase caused in the TV by the first series of pulses; especially in the case of $1250 \mathrm{~V} \cdot \mathrm{cm}^{-1}$. In case of control, the cuvette remained in the bolus for $90 \mathrm{~s}$ without electroporation during the period $t_{3} \rightarrow t_{4}$ in Figure 4. For the electric-field strength $1250 \mathrm{~V} \cdot \mathrm{cm}^{-1}$, the H-pump had to be switched to the C-pump for the temperature to remain within the accuracy of $\pm 1.5^{\circ} \mathrm{C}$ with respect to $\mathrm{T}_{\text {target }}\left(\mathrm{t}_{3} \rightarrow \mathrm{t}_{4}\right.$ in Figure 4$)$. We chose $\pm 1.5^{\circ} \mathrm{C}$ as the maximal fluctuation range, since we noticed that during the IRE-treatment the temperature fluctuated between $\mathrm{T}_{\text {target }}$ and $\mathrm{T}_{\text {target }} \pm 1.5^{\circ} \mathrm{C}$ for $1250 \mathrm{~V} \cdot \mathrm{cm}^{-1}$. For $500 \mathrm{~V} \cdot \mathrm{cm}^{-1}$, the H-pump was only used since the temperature stability remained within $\pm 1.5^{\circ} \mathrm{C}$. At the end of the treatment, the pumps were turned off, and the cuvette was returned into the fume hood ( $t_{4} \rightarrow t_{5}$ in Figure 4$)$. 

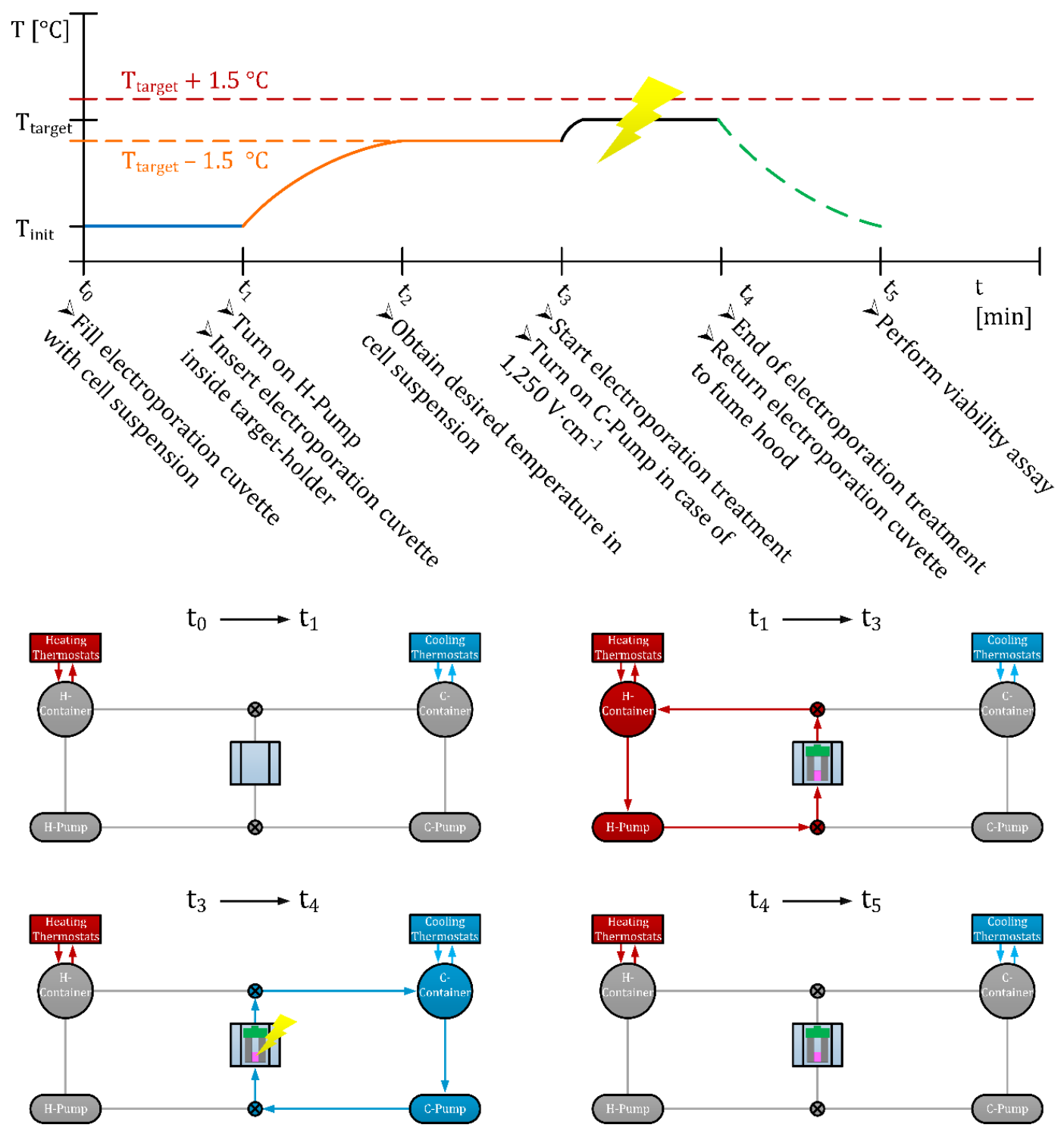

Figure 4. Time scheme of the application of HyCHEED in vitro. Please note that the red and orange dotted lines represent the temperature fluctuations around $T_{\text {target }}$. Also note that at $t_{3} H$-Pump was switched to C-Pump when $1250 \mathrm{~V} \cdot \mathrm{cm}^{-1}$ was used.

\subsection{Evaluation of In Vitro Experiments Using HyCHEED}

HyCHEED can be used to perform in vitro IRE experiments at a pre-defined temperature level, as illustrated next. The evaluation of the in vitro experiments can be done by performing the cell viability assays in which a reagent is added to the cell suspension to quantitatively measure the proliferation of the living cells. Also, a typical characteristic of electroporation can be used as the evaluation process, namely the change in electrical specific conductivity $\left(\sigma\left[\mathrm{S} \cdot \mathrm{m}^{-1}\right]\right)$. Previously, it was noted that the pore formation of the cells during IRE results in the increase of $\sigma$ in the tissue [4]. Specifically, the change in the $\sigma$ depends on the pulse settings (e.g., E and pulse number) and the temperature of the tissue [20]. To evaluate the in vitro experiments, the $\sigma$ will be established during treatment of the first and the last pulse (90th), and directly after the treatment. For each assessment, $\mathrm{n}=3$ experiments were performed. More details are provided in the subsequent paragraphs. 


\subsubsection{Establishing the Electrical Specific Conductivity of the Target Volume}

To evaluate the in vitro experiments, the average electrical specific conductivity $\left(\sigma_{\mathrm{av}}\left[\mathrm{S} \cdot \mathrm{m}^{-1}\right]\right)$ will be used to determine the influence of temperature levels and electric-field strength on the pulse number. This will be done by calculating the ratio of the $\sigma_{\mathrm{av}}$ between the 90th and the first pulse. In addition, we will determine the influence of temperature and electric-field strength effects on the post-treatment $\sigma_{\mathrm{av}}$, which is the $\sigma_{\mathrm{av}}$ that is determined in $\sim 30 \mathrm{~s}$ after treatment. Specifically, we will calculate the ratio between the post-treatment $\sigma_{\mathrm{av}}$ of the treatments with respect to the post-treatment $\sigma_{\mathrm{av}}$ of the control at $37^{\circ} \mathrm{C}$. Finally, to determine the influence of the presence of the electric field on $\sigma_{\mathrm{av}}$, we will compare the $\sigma_{\mathrm{av}}$ values of the 90th pulse with the post-treatment $\sigma_{\mathrm{av}}$.

The average electrical specific conductivity of the cell suspension was determined using Ohm's law,

$$
\frac{\Phi}{\mathrm{I}}=\frac{1}{\sigma_{\mathrm{av}}} \cdot \frac{\mathrm{d}}{\mathrm{A}}
$$

where $\Phi[\mathrm{V}]$ is the measured voltage, I [A] is the measured electric current, $\mathrm{d}[\mathrm{m}]$ is the distance between the electrode plates, and $\mathrm{A}\left[\mathrm{m}^{2}\right]$ is the surface of the TV that is contacting the electrode plate. To determine the change in the $\sigma_{\mathrm{av}}$ of the 90th pulse with respect to the first pulse, the $\sigma_{\mathrm{av}}$ values were calculated considering the extremities at the right side of the electric current and voltage of both the first and the 90th pulses (see the arrows representing the extremities at the right side in Figure 5A). Please note that, for the calculation of the $\sigma_{\mathrm{av}}$ values, the surface A was calculated by considering the initial height of the TV for the first pulse before its placement in the water bolus. For the 90th pulse, the height of the TV was considered after the removal of the cuvette from the bolus.
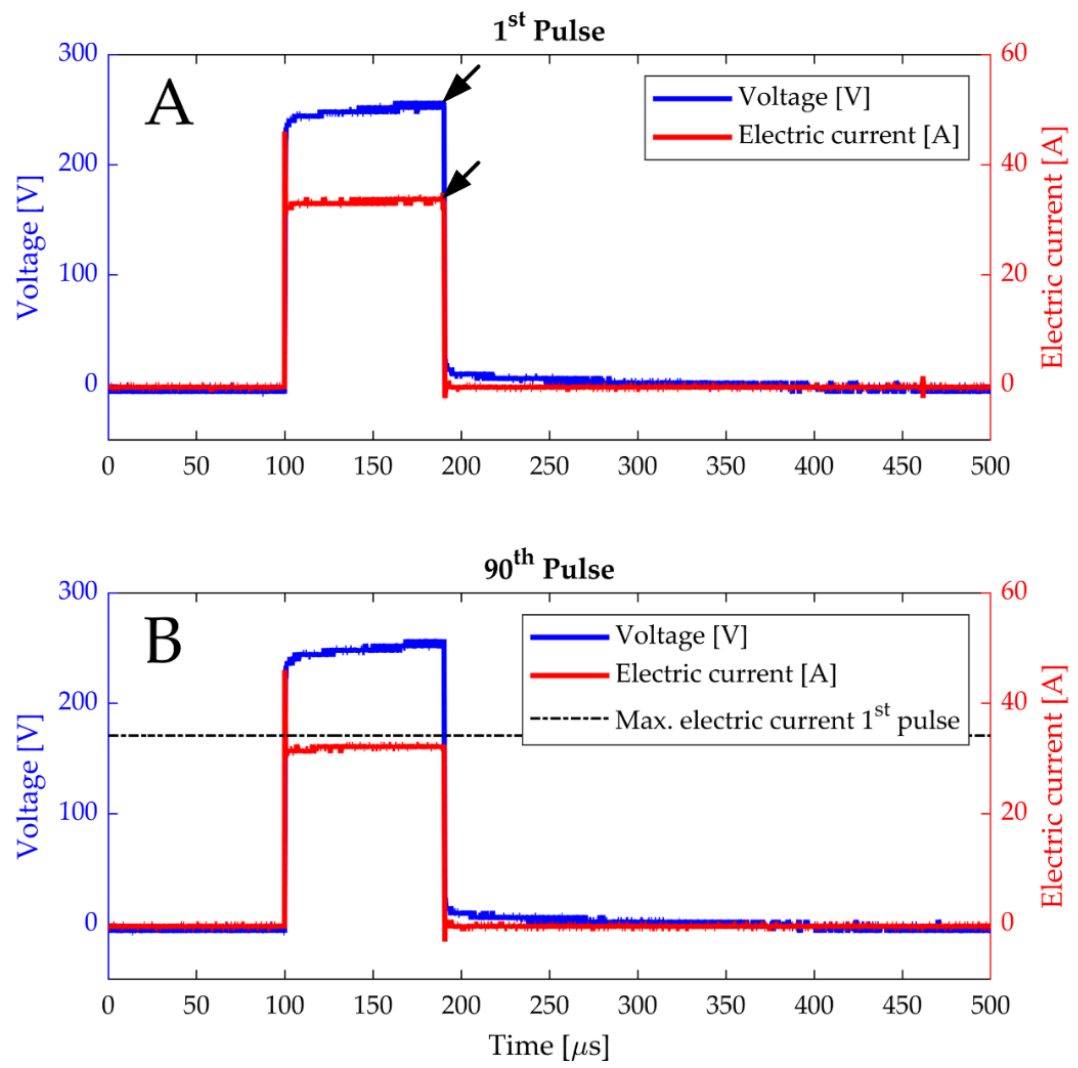

Figure 5. The electric current and voltage for $1250 \mathrm{~V} \cdot \mathrm{cm}^{-1}$ of (A) the first and (B) the 90th (last) pulse number as a function of time. In (B), a horizontal line was added to show the maximum of the electric current at the end of the first pulse. Also note that the black arrows in (A) represent the values of the electric current and voltage used in the calculation of the average electrical specific conductivity $\left(\sigma_{\mathrm{av}}\left[\mathrm{S} \cdot \mathrm{m}^{-1}\right]\right)$. 
Around $30 \mathrm{~s}$ after the end of the control/treatment, before the removal of the electroporation cuvette from the bolus, a $\sim 10 \mathrm{~V}$ pulse was applied to the TV. This $10 \mathrm{~V}$ is equivalent to $50 \mathrm{~V} \cdot \mathrm{cm}^{-1}$, which is below reversible electroporation threshold [32]. For the calculation of the post-treatment $\sigma_{\mathrm{av}}$ value, the surface A was calculated considering the height of the TV after the removal of the cuvette from the bolus.

\subsubsection{Cell Viability Assays/Reagents}

To determine the cell viability after the controls/IRE-treatments, cell viability was assessed using PrestoBlue $^{\mathrm{TM}}$ cell viability assay and Trypan blue stain assay. The PrestoBlue ${ }^{\mathrm{TM}}$ cell viability assay is a non-toxic resazurin-based method that functions as a cell viability indicator. Specifically, the metabolically active cells reduce the non-fluorescent blue dye (resazurin) into a highly fluorescent pink dye (resorufin) that can be quantitatively evaluated using fluorescence or absorbance measurements [33]. The Trypan blue stain assay is based on the Trypan blue diazo dye that is characterized by a molecular weight of 960 DA [34,35]. This molecule is a cell membrane-impermeable that can only enter the cytoplasm of the cell in case of compromised cell membrane, e.g., in case of reversible/irreversible electroporation and cell death. This assay could also be used to determine the cell concentration of the cell suspension as was done in this study.

After returning the electroporation cuvette to the fume hood post-treatment, the cell suspension was resuspended in the cuvette. Next, a total of $20.0 \mu \mathrm{L}$ cell suspension was obtained and mixed with $20.0 \mu \mathrm{L}$ Trypan Blue (Sigma-Aldrich, Saint Louis, MO, USA). Afterwards, $11.8 \mu \mathrm{L}$ was inserted inside a cell counting slide (LUNA ${ }^{\mathrm{TM}}$ Cell Counting Slides, Aligned Genetics, Inc., Anyang-si, South Korea) and the immediate cell viability and cell concentration were determined using the automated bright-field cell counter (LUNA ${ }^{\mathrm{TM}}$ Automated Cell Counter, Aligned Genetics, Inc., Anyang-si, Korea) with a lens magnification of 1.47 . The Trypan blue stain assay was performed $\sim 8 \mathrm{~min}$ after the controls/IRE-treatments. Please note that the same protocol was used to determine the cell concentration of the cell suspension. Also note that this assay might provide an underestimation of the cell viability if applied within $10 \mathrm{~min}$ after treatment, due to the possible staining of viable reversibly electroporated cells. In addition, a number of cells within the TV could need more time to relapse or to recover, which could further reduce the accuracy of this assay. Therefore, in this study the cell viability was mainly determined using PrestoBlue ${ }^{\mathrm{TM}}$ cell viability assay, to provide more time ( $\sim 2$ days) for cell recovery or cell relapse. The Trypan blue stain assay was only used to present the cell morphology and viability before and after IRE-treatment.

For the PrestoBlue ${ }^{\mathrm{TM}}$ cell viability assay, $6.3 \mu \mathrm{L}$ of the treated cell suspension was plated in a 96 well plate that was returned to the incubator at the end of the experiment. After $\sim 2$ days, the old DMEM was removed and a $100.0 \mu \mathrm{L}$ fresh DMEM including a 10 times diluted Molecular Probes ${ }^{\mathrm{TM}}$ PrestoBlue ${ }^{\mathrm{TM}}$ Cell Viability Reagent (Thermo Fisher Scientific, Waltham, MA, USA) was added to the wells that contain cells. Subsequently, the well plate was returned to the incubator. After $\sim 5 \mathrm{~h}$, the change in the fluorescence of the PrestoBlue reagent due to the presence of viable cells was measured using Synergy 2 Multi-Mode Microplate Reader (BioTek, Agilent Technologies, Winooski, VT, USA) with the excitation/emission wavelengths set at $560 / 590 \mathrm{~nm}$.

\subsubsection{Statistical Analyses}

In this study the data are presented as mean \pm standard deviation $( \pm \mathrm{SD})$ of at least three independent experiments. Furthermore, a two-tailed Student's t-test (two groups; unequal variance) was utilized to determine the significant difference between temperatures for every experiment. The criterion for statistical significance was set to be $p<0.05$. The statistical analyses were performed using Excel 2016 (Microsoft Office, Microsoft, Redmond, WA, USA). 


\section{Results}

\subsection{Validation of HyCHEED}

\subsubsection{Read-Outs of Electrical Parameters}

To demonstrate the capability of HyCHEED in producing typical clinical electroporation pulses, examples of the electric current and voltage readouts of the first and the 90th pulse are presented in Figure 5 for $1250 \mathrm{~V} \cdot \mathrm{cm}^{-1}$ at $46^{\circ} \mathrm{C}$. Here, the maximal electric current and voltage were $34.1 \mathrm{~A}$ and $\sim 254 \mathrm{~V}$ during the first pulse, and $32.5 \mathrm{~A}$ and $\sim 254 \mathrm{~V}$ during the 90th pulse. At the 90th pulse, the electric current was slightly reduced due to the reduction of the height of the target volume (TV) caused by gas formation as a result of water electrohydrolysis [36]. Specifically, for $1250 \mathrm{~V} \cdot \mathrm{cm}^{-1}$ the initial height of the TV $(\sim 15 \mathrm{~mm})$ decreased with $\sim 1 \mathrm{~mm}(\sim 7 \%)$ at $37^{\circ} \mathrm{C}$ and $\sim 2 \mathrm{~mm}(\sim 13 \%)$ at $46{ }^{\circ} \mathrm{C}$, while the height for $500 \mathrm{~V} \cdot \mathrm{cm}^{-1}$ decreased far less than $1 \mathrm{~mm}$ at $37^{\circ} \mathrm{C}$ and $46^{\circ} \mathrm{C}$. Despite the increase in the electrical specific conductivity $\left(\sigma\left[\mathrm{S} \cdot \mathrm{m}^{-1}\right]\right)$ of the TV during the IRE treatment in case of Figure 5, the trade-off between the increase in the $\sigma$ and reduction in the height of the TV resulted in the slightly decrease of the electric current in the last pulse with respect to the first pulse.

Furthermore, the shapes of the electric current and voltage resemble the shapes of typical electroporation pulses shown in Figure 8 of [37]. Specifically, the peak at the start of the electric current is generated due to the movements of charged ions and molecules, and the reorientation of the electric dipoles, after which the electric current slightly increases due to the pore formations in the cell membranes [38].

\subsubsection{Temperature Measurements}

Figure 6 illustrates the average temperature evolution over time in the electroporation cuvette during the IRE-treatment. Here, the temperature evolution was provided as an example and omitted in the rest of the experimental results. The time between the insertion of the cuvette in the T-holder and the start of the treatment is $\sim 2.3 \mathrm{~min}$. The mean temperatures over the treatment time are shown in Table 2 demonstrate that $\mathrm{T}_{\text {target }}$ could be obtained within $\pm 1.5^{\circ} \mathrm{C}$ with respect to desired temperature, independent of the selection of $\mathrm{T}_{\text {target}}$, or the pulse settings.

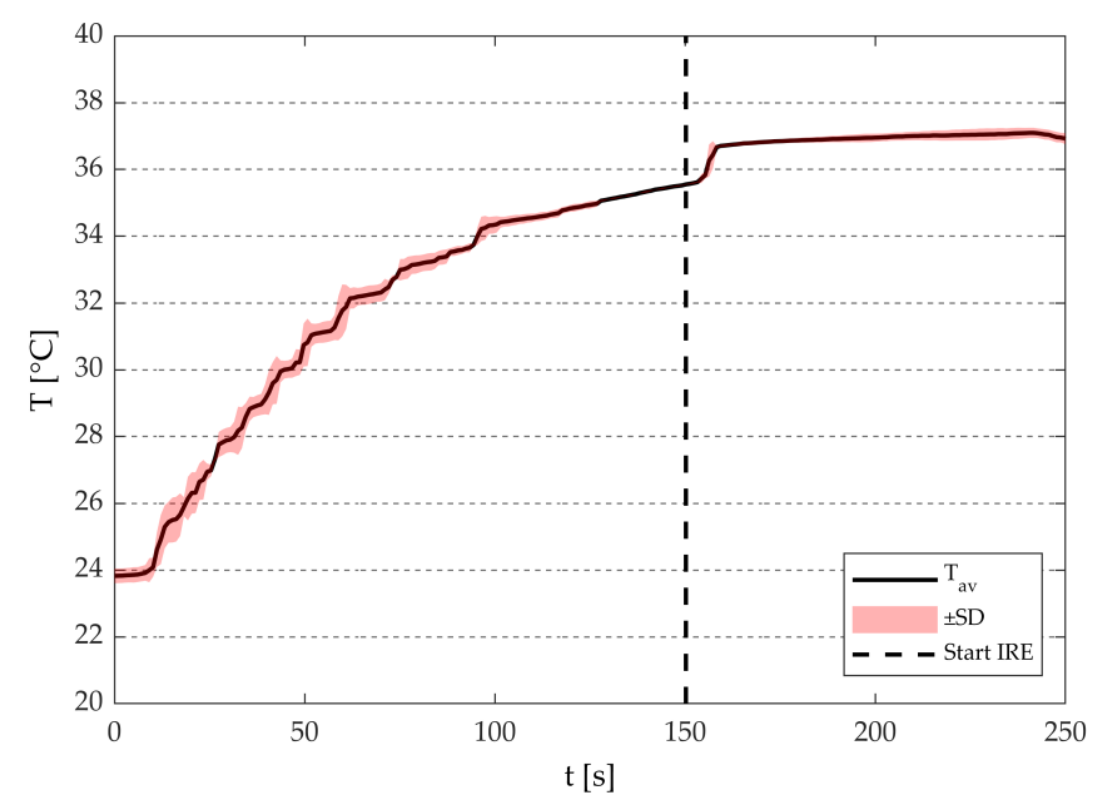

Figure 6. An illustration of the average temperature evolution over time $\left(\mathrm{T}_{\mathrm{av}} ; \mathrm{n}=3\right)$ during the treatment at $37^{\circ} \mathrm{C}$ for $1250 \mathrm{~V} \cdot \mathrm{cm}^{-1}$. The solid line represents the average temperature, pink area represents the standard deviation $( \pm \mathrm{SD})$, and the dashed line represents the start of the IRE treatment. 
Table 2. The mean temperature over the treatment time $(n=3$; including $\pm S D)$ acquired from the treatments as a function of target temperature $\left(\mathrm{T}_{\text {target }}\left[{ }^{\circ} \mathrm{C}\right]\right)$ and electric-field strength $\left(\mathrm{E}\left[\mathrm{V} \cdot \mathrm{cm}^{-1}\right]\right)$.

\begin{tabular}{ccc}
\hline \multirow{2}{*}{$\mathbf{T}_{\text {target }}\left[{ }^{\circ} \mathbf{C}\right]$} & \multicolumn{2}{c}{$\mathrm{E}\left[\mathrm{V} \cdot \mathbf{c m}^{-\mathbf{1}}\right]$} \\
\cline { 2 - 3 } & $\mathbf{5 0 0}$ & $\mathbf{1 2 5 0}$ \\
\hline $\mathbf{3 7}$ & $36.75 \pm 0.58$ & $36.86 \pm 0.34$ \\
$\mathbf{4 6}$ & $46.44 \pm 0.82$ & $46.66 \pm 0.70$ \\
\hline
\end{tabular}

3.2. Effects of Thermally Controlled Irreversible Permeabilization on the Electrical Specific Conductivity and Cell Viability

\subsubsection{Electrical Specific Conductivity}

Figure 7 shows the $\sigma_{\mathrm{av}}$ ratios of the 90th pulse (Figure 7A) and the post-treatment (Figure 7B) with respect to the post-treatment $\sigma_{\mathrm{av}}$ of the control at $37^{\circ} \mathrm{C}$ as a function of electric-field strength and target temperature. The data, including the $\sigma_{\mathrm{av}}$ of the culture medium excluding cells, are provided in Supplementary Materials. These results illustrate increase of $\sigma_{\mathrm{av}}$ ratio with respect to the control at $37^{\circ} \mathrm{C}$ as a function of the following effects:

1. Temperature only:

a. In Figure $7 \mathrm{~B}$, the $\sigma_{\mathrm{av}}$ ratio for the control at $46{ }^{\circ} \mathrm{C}$ increased by 1.2 -fold with respect to the control at $37^{\circ} \mathrm{C}$.

2. Electric-field strength only; during the pulse in the presence of the electric field (focus on Figure 7A):

a. In Figure $7 \mathrm{~A}$, the $\sigma_{\mathrm{av}}$ ratios for $1250 \mathrm{~V} \cdot \mathrm{cm}^{-1}$ at $37^{\circ} \mathrm{C}$ and $46^{\circ} \mathrm{C}$ increased by 2.5 and 2.9 -folds, while the $\sigma_{\mathrm{av}}$ ratios for $500 \mathrm{~V} \cdot \mathrm{cm}^{-1}$ at $37^{\circ} \mathrm{C}$ and $46^{\circ} \mathrm{C}$ increased by 2.0 and 2.4-folds.

b. In Figure $7 \mathrm{~B}$ the $\sigma_{\mathrm{av}}$ ratio for the control at $46^{\circ} \mathrm{C}$ increased by 1.2 -fold, while in Figure $7 \mathrm{~A}$, the $\sigma_{\mathrm{av}}$ ratios for $500 \mathrm{~V} \cdot \mathrm{cm}^{-1}$ and $1250 \mathrm{~V} \cdot \mathrm{cm}^{-1}$ at $46{ }^{\circ} \mathrm{C}$ increased by 2.4 and 2.9 -fold.

3. Electric-field strength only; post-treatment in the absence of the electric field (focus on Figure 7B):

a. In Figure $7 \mathrm{~B}$, the $\sigma_{\mathrm{av}}$ ratios for $1250 \mathrm{~V} \cdot \mathrm{cm}^{-1}$ at $37^{\circ} \mathrm{C}$ and $46^{\circ} \mathrm{C}$ increased by 1.2 and 2.1 -folds, while the $\sigma_{\mathrm{av}}$ ratios for $500 \mathrm{~V} \cdot \mathrm{cm}^{-1}$ at $37^{\circ} \mathrm{C}$ and $46^{\circ} \mathrm{C}$ increased by 1.1 and 1.6 -folds.

b. In Figure $7 \mathrm{~B}$, the $\sigma_{\mathrm{av}}$ ratio for the control at $46^{\circ} \mathrm{C}$ increased by 1.2 -fold, while in the $\sigma_{\mathrm{av}}$ ratios for $500 \mathrm{~V} \cdot \mathrm{cm}^{-1}$ and $1250 \mathrm{~V} \cdot \mathrm{cm}^{-1}$ at $46^{\circ} \mathrm{C}$ increased by 1.6 and 2.1 -fold.

4. Presence of electric field during the treatment:

a. In Figure $7 \mathrm{~A}$, the $\sigma_{\mathrm{av}}$ ratios for $500 \mathrm{~V} \cdot \mathrm{cm}^{-1}$ and $1250 \mathrm{~V} \cdot \mathrm{cm}^{-1}$ during the 90 th pulse at $37^{\circ} \mathrm{C}$ increased by 2.0 and 2.5-folds, while in Figure $7 \mathrm{~B}$ the $\sigma_{\mathrm{av}}$ ratio post-treatment increased by 1.11 and 1.64-folds for the same treatment parameters.

b. In Figure $7 \mathrm{~A}$, the $\sigma_{\mathrm{av}}$ ratios for $500 \mathrm{~V} \cdot \mathrm{cm}^{-1}$ and $1250 \mathrm{~V} \cdot \mathrm{cm}^{-1}$ during the 90 th pulse at $46{ }^{\circ} \mathrm{C}$ increased by 2.4 and 2.9-folds, while in Figure $7 \mathrm{~B}$ the $\sigma_{\mathrm{av}}$ ratio post-treatment increased by 1.2 and 2.1-folds for the same treatment parameters.

5. Combined effects of electric-field strength and temperature; during the 90th pulse in the presence of the electric field (focus on Figure 7A):

a. In Figure $7 \mathrm{~A}$, the $\sigma_{\mathrm{av}}$ ratios for $500 \mathrm{~V} \cdot \mathrm{cm}^{-1}$ and $1250 \mathrm{~V} \cdot \mathrm{cm}^{-1}$ during the 90 th pulse at $46{ }^{\circ} \mathrm{C}$ increased by 2.4 and 2.9 -folds, while the $\sigma_{\mathrm{av}}$ ratios for the same pulse parameters at $37^{\circ} \mathrm{C}$ increased by 2.0 and 2.5 -folds.

6. Combined effects of electric-field strength and temperature; post-treatment in the absence of the electric field (focus on Figure 7B): 
a. In Figure $7 \mathrm{~B}$, the $\sigma_{\mathrm{av}}$ ratios for $500 \mathrm{~V} \cdot \mathrm{cm}^{-1}$ and $1250 \mathrm{~V} \cdot \mathrm{cm}^{-1}$ post-treatment at $46^{\circ} \mathrm{C}$ increased by 1.2 and 2.1 -folds, while the $\sigma_{\mathrm{av}}$ ratios for the same pulse parameters at $37^{\circ} \mathrm{C}$ increased by 1.1 and 1.6 -folds.
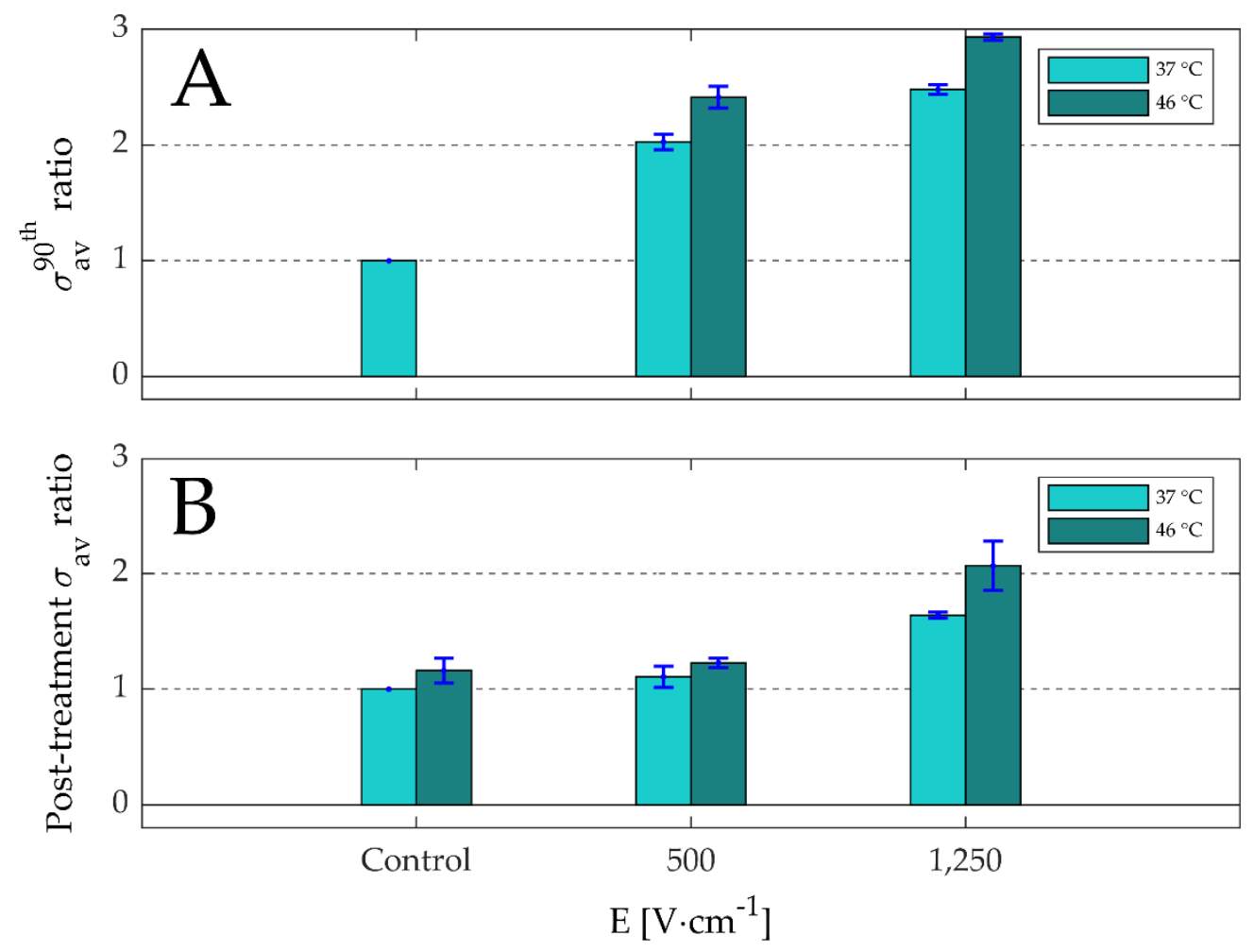

Figure 7. The ratios of the average electrical conductivities $\left(\sigma_{\mathrm{av}}\left[\mathrm{S} \cdot \mathrm{m}^{-1}\right]\right)$ of the 90 th pulse $(\mathbf{A})$ and post-treatment $(\mathbf{B})$ with respect to the post-treatment $\sigma_{\mathrm{av}}$ of the control at $37^{\circ} \mathrm{C}\left(0.75 \mathrm{~S} \cdot \mathrm{m}^{-1}\right)$ are shown as a function of the electric-field strength $\left(\mathrm{E}\left[\mathrm{V} \cdot \mathrm{cm}^{-1}\right]\right)$ and target temperature $(\mathrm{n}=3$; including $\pm \mathrm{SD})$. The data are provided in Supplementary Materials. Note that the post-treatment $\sigma_{\mathrm{av}}$ was measured at about $30 \mathrm{~s}$ after the 90th pulse.

In Figure 8 , the ratios between the $\sigma_{\mathrm{av}}$ of the $90^{\text {th }}$ pulse and the first pulse are presented as a function of electric-field strength and target temperature to determine the influence of the pulse number. The data used in this figure are provided in Supplementary Materials Table S2. These results reveal that for $500 \mathrm{~V} \cdot \mathrm{cm}^{-1}$, the $\sigma_{\mathrm{av}}$ of the 90th pulse is slightly lower than the $\sigma_{\mathrm{av}}$ of the first pulse, with an average ratio of $\sim 0.95$, while for $1250 \mathrm{~V} \cdot \mathrm{cm}^{-1}$, the $\sigma_{\mathrm{av}}$ of the 90th pulse is slightly higher than the $\sigma_{\mathrm{av}}$ of the first pulse, with an average ratio of $\sim 1.05$, implying that $\sigma_{\mathrm{av}}$ hardly increase as function of pulse number. Furthermore, Figure 8 also demonstrates that increase in temperature results in the increase of the $\sigma_{\mathrm{av}}$ ratios, implying that higher temperatures would increase the electrical specific conductivity of the target volume during IRE. 


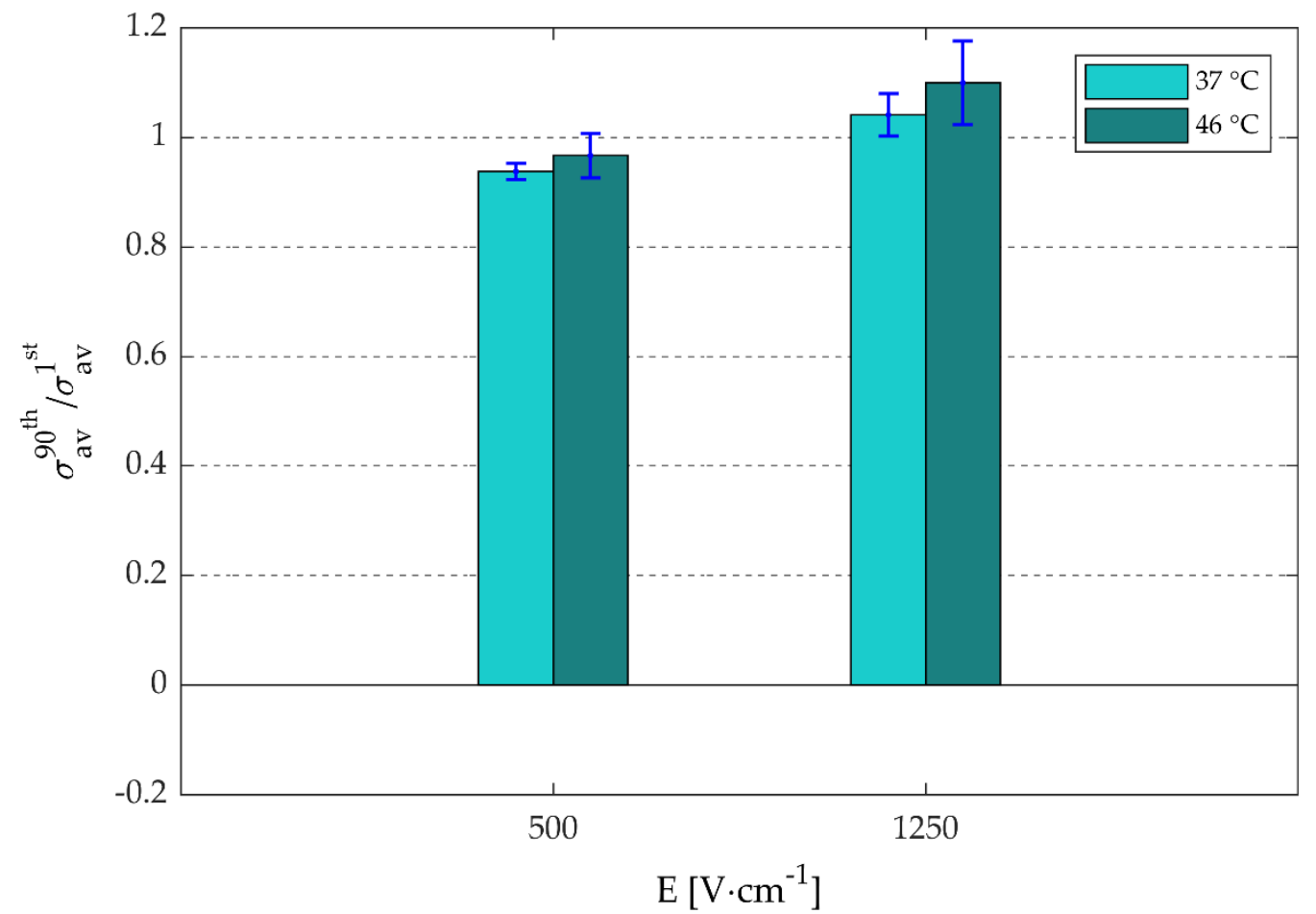

Figure 8. The average ratio $(n=3$; including $\pm S D)$ between the average electric conductivities $\left(\sigma_{\mathrm{av}}\left[\mathrm{S} \cdot \mathrm{m}^{-1}\right]\right)$ of the 90 th and the first pulse are shown as a function the electric-field strength $\left(\mathrm{E}\left[\mathrm{V} \cdot \mathrm{cm}^{-1}\right]\right)$ and target temperatures. The data are provided in Supplementary Materials Table S2.

\subsubsection{Cell Viability}

Figure 9 shows examples of the viability assay of untreated and treated cell suspensions at $37^{\circ} \mathrm{C}$. Specifically, the cell suspension in Figure 9A was an untreated control and had a cell concentration of $1.17 \cdot 10^{6}$ cells $\cdot \mathrm{mL}^{-1}$, while the cell suspension in Figure $9 \mathrm{~B}$ was exposed to $1250 \mathrm{~V} \cdot \mathrm{cm}^{-1}$ and had a much reduced cell concentration of $0.04 \cdot 10^{6}$ cells $\mathrm{mL}^{-1}$ (i.e., $97 \%$ cell death). Since HyCHEED is capable of performing irreversible electroporation treatment while maintaining a stable predefined temperature, these results show that irreversible permeabilization at $1250 \mathrm{~V} \cdot \mathrm{cm}^{-1}$ is sufficient to induce cell ablation with limited addition of heat.

In Figure 10, the viability ratio of the cell suspensions are presented as a function of electric-field strength and target temperature. As in Figure 7, this figure also shows cell death as a function of (1) only temperature (control, $\left.46^{\circ} \mathrm{C}\right),(2)$ only irreversible permeabilization effect $\left(1250 \mathrm{~V} \cdot \mathrm{cm}^{-1}\right.$, $37^{\circ} \mathrm{C}$ ), and (3) combined effects of irreversible permeabilization and temperature $\left(500 \mathrm{~V} \cdot \mathrm{cm}^{-1}, 46^{\circ} \mathrm{C}\right)$. Specifically, it shows that the exposure of untreated cell suspension to $46^{\circ} \mathrm{C}$ for $\sim 2-3$ min results in $15 \%$ of thermal ablation. By treating the cells with $500 \mathrm{~V} \cdot \mathrm{cm}^{-1}$, a total cell death of $70 \%$ was obtained at $37^{\circ} \mathrm{C}$, which increases to $90 \%$ at $46^{\circ} \mathrm{C}$ due to an additional combined thermal-IPE ablation. For the treatment of the cells with $1250 \mathrm{~V} \cdot \mathrm{cm}^{-1}$, a total ablation of $100 \%$ was obtained for both $37^{\circ} \mathrm{C}$ and $46^{\circ} \mathrm{C}$. These results show that, at relatively low electric-field strengths, temperature not only plays a significant role in the increase of the electrical specific conductivity of the target volume, but also in the increase of the cell death in the target tissue. 


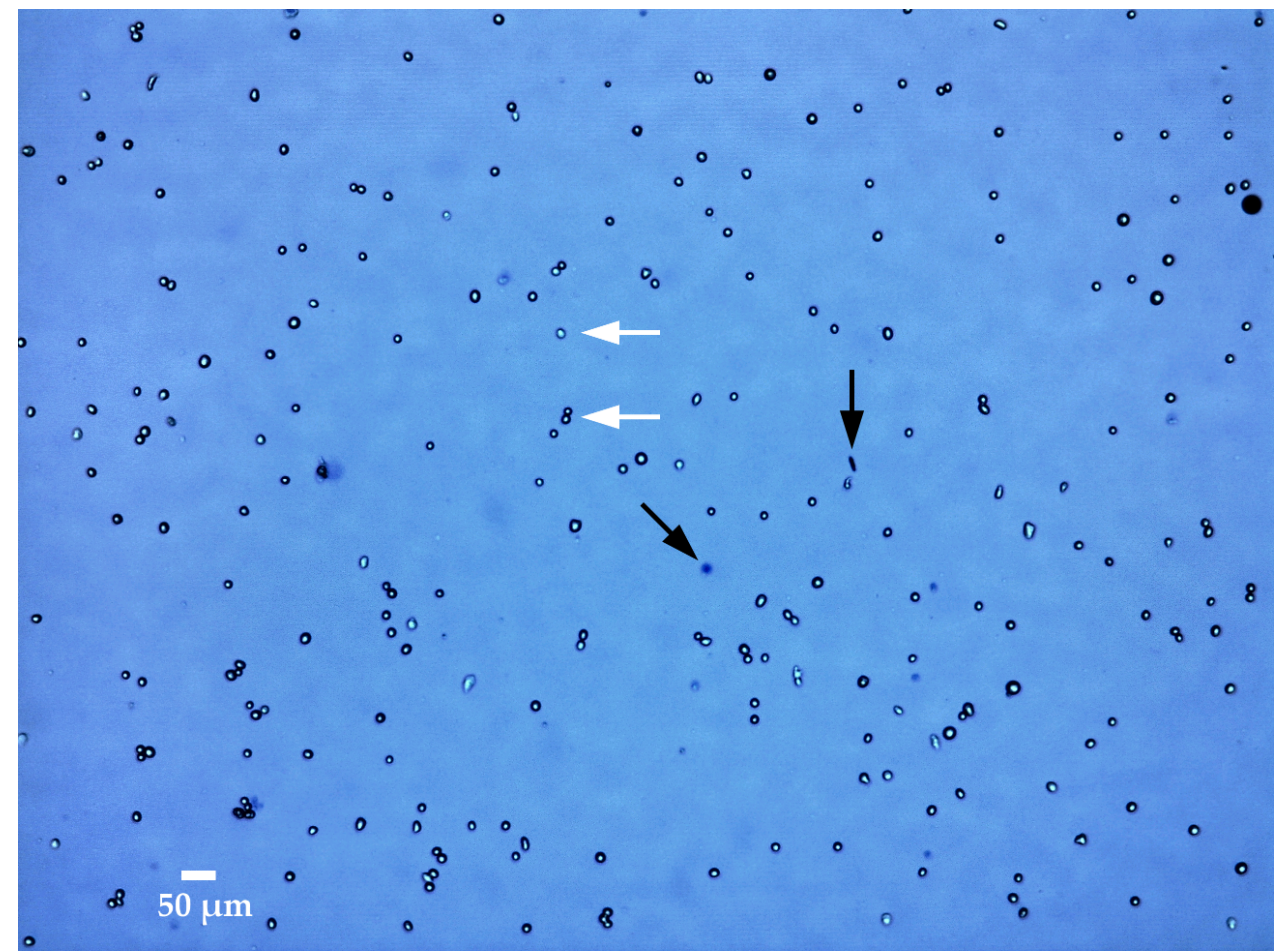

(A)

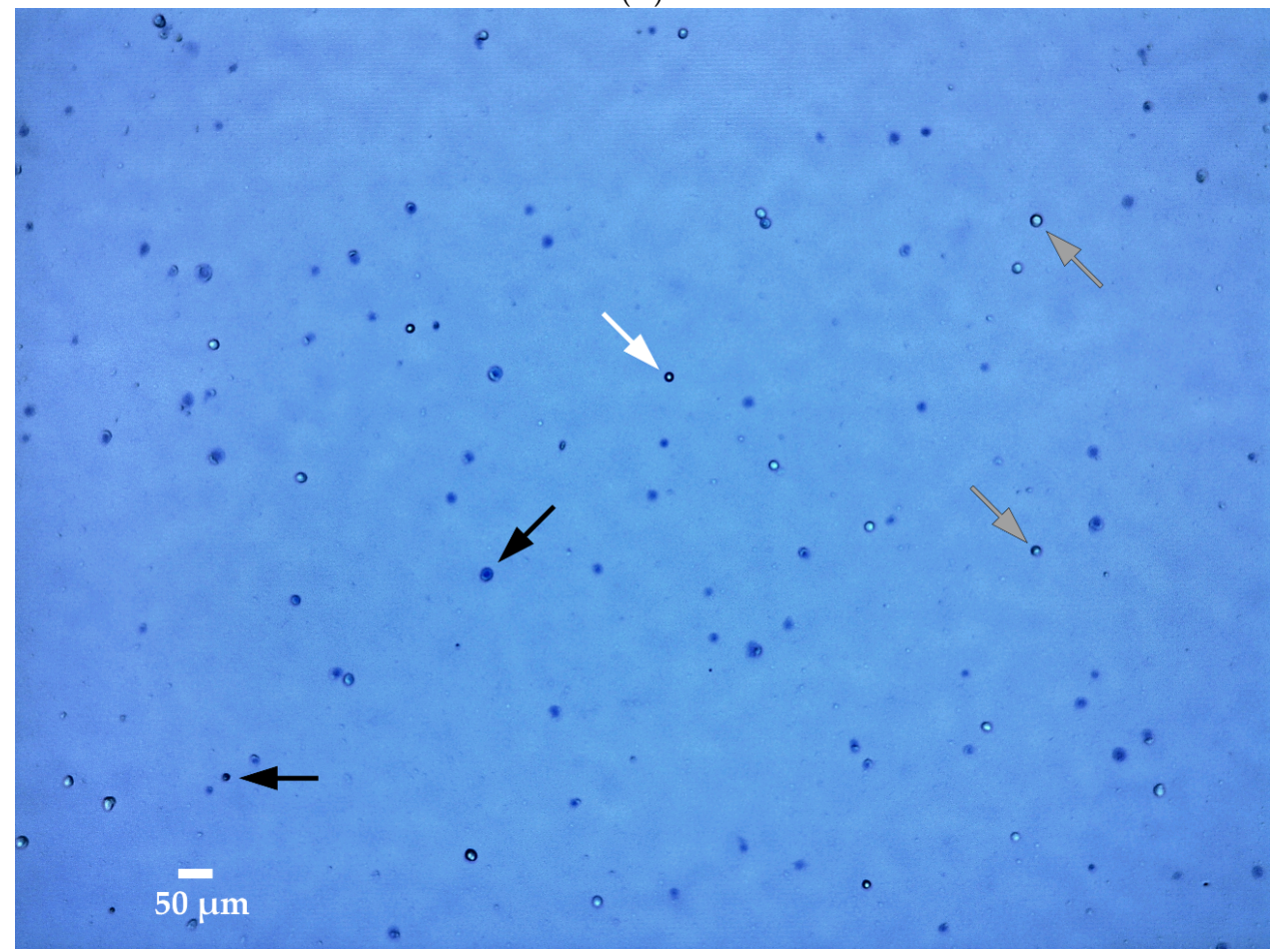

(B)

Figure 9. Example of cell viability assay (Trypan blue assay) performed on the cell suspension maintained at $37^{\circ} \mathrm{C}$ (A) without the application of irreversible electroporation, and (B) after application of irreversible electroporation (electric field strength of $1250 \mathrm{~V} \cdot \mathrm{cm}^{-1}$ ). The length of the scale bar in both images represents $50 \mu \mathrm{m}$. Vital cells are noted by light blue circles with dark edges (indicated by white arrows), while electroporated cells are noted by blue circles with less dark edges (indicated by gray arrows) and dead or dying cells are noted by dark blue, or dim circles (indicated by black arrows). Note that the cell viability was determined using an automated bright-field cell counter (LUNA ${ }^{\mathrm{TM}}$ Automated Cell Counter, Aligned Genetics, Anyang-si, Inc., South Korea) with a lens magnification of 1.47 . 


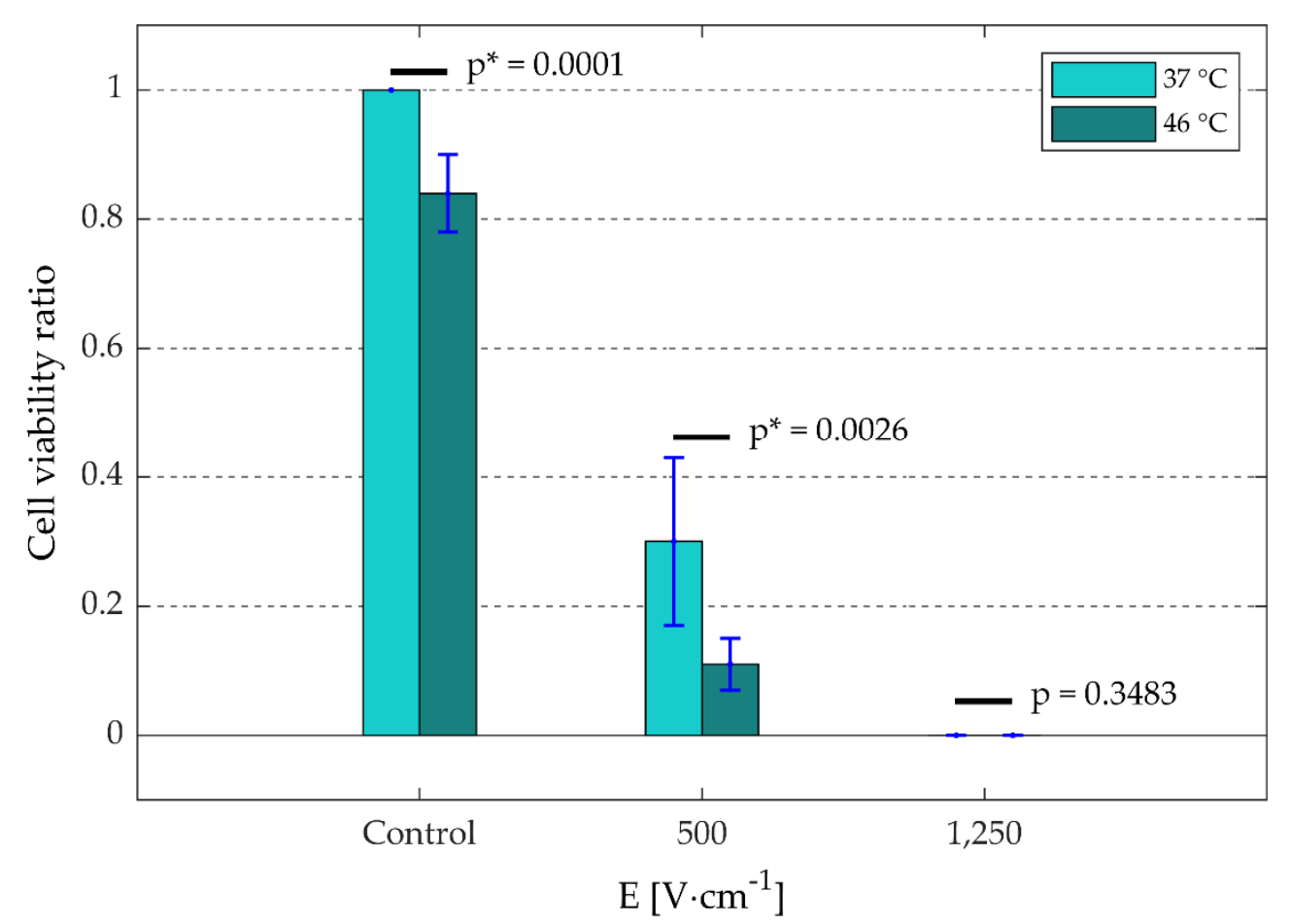

Figure 10. The cell viability ratio $(n=3$; including $\pm S D)$ of cell suspensions as a function of electric-field strength $\left(\mathrm{E}\left[\mathrm{V} \cdot \mathrm{cm}^{-1}\right]\right)$ and target temperature with respect to the control at $37^{\circ} \mathrm{C}$. For both control and $500 \mathrm{~V} \cdot \mathrm{cm}^{-1}$, the cell viability ratio at $46^{\circ} \mathrm{C}$ significantly differ from the ratio at $37^{\circ} \mathrm{C}(p \leq 0.0026$; * indicates significant difference). Please note that during the control/treatments, the culture medium was used in the cell suspension.

\section{Discussion}

\subsection{Main Research Objective: HyCHEED Was Validated}

This study demonstrated that the hydraulically controllable heat exchange electroporation device (HyCHEED) is capable of applying steady electrical pulses to the target volume (Figure 5) while maintaining stable temperatures during the electroporation treatment for clinically relevant temperatures and electroporation settings. This was done while limiting temperature fluctuations to $\pm 1.5^{\circ} \mathrm{C}$, as was shown in Figure 6 and Table 2. In addition, the proper performance of HyCHEED was evident from the dependence of the cell viability in Figures 9 and 10 on target temperature and electric-field strength, corresponding to the data from the previous studies $[27,28]$. Specifically, increase of target temperatures and electric field results in increase of cell death.

\subsection{Secondary Research Objective: Irreversible Electroporation Characteristics Are Influenced by Electric-Field Strength and Temperature}

In this study we showed that the increase of cell death (Figure 10) and electrical specific conductivity (Figure 7) due to IRE depends on electric-field strength, temperature, and the combined effects of both parameters. These findings correspond with the conclusion in our previous study [20], in which we reported the presence of these effects in the IRE-treated regions. In our previous study, we performed a systematic review using various numerical models from the literature to assess the degree of mild-hyperthermic and thermally ablative effects caused by IRE within IRE-treated region. We concluded that while $5 \%$ of the IRE-treated region was thermally ablated, in $30 \%$ of the treated region, a combined effect of both elevated temperature and irreversible permeabilization occurs. The remaining $65 \%$ ablation was only caused by irreversible permeabilization. The results in this study signify the feasibility of the presence of these effects during a typical clinical IRE treatment, 
depending on the spatially-temporally depended magnitudes of the electric-field strength and the temperature increase.

Moreover, Figure 7 also showed the dependence of the electrical specific conductivity post-treatment on the electric-field strength, temperature, and combined effects of both parameters, even after the electric field was switched off after treatment. In addition, it shows that the electrical specific conductivity decreases after treatment, which could be attributed to membrane resealing at the end of the treatment, as was shown in Ivorra et al. [39,40]. Ivorra et al. investigated the electrical specific conductivity within, in between, and after (reversible and irreversible) electroporation pulses in healthy and cancerous tissue in rodents. Similarly, they found a rapid drop in the electrical specific conductivity after electroporation.

Furthermore, Figure 8 shows that the electrical specific conductivity ratios between the 90th and the first pulses are almost equal to 1 for $500 \mathrm{~V} \cdot \mathrm{cm}^{-1}$ and $1250 \mathrm{~V} \cdot \mathrm{cm}^{-1}$. Accordingly, the combined results of both Figures 7A and 8 suggests that the electrical specific conductivity mainly depends on the electric field and temperature, and less on the pulse number. These results are in accordance with the previous studies, which also showed that the electrical specific conductivity ratios between the last and the first pulses are $\sim 1$ in case of eight pulses $[39,41]$. It must be noticed that, in Figure 8 , the average ratio is slightly below 1 for $500 \mathrm{~V} \cdot \mathrm{cm}^{-1}$, while it is slightly above 1 for $1250 \mathrm{~V} \cdot \mathrm{cm}^{-1}$. This can be explained by the combined effects of electrical specific conductivity increase and height reduction of the target volume caused by gas formation as a result of water electrohydrolysis. E.g., despite the decrease of the height of the target volume for $1250 \mathrm{~V} \cdot \mathrm{cm}^{-1}$ in the order of $1.5 \mathrm{~mm}$, an almost complete ablation was performed, with as a result a slight increase in the $\sigma_{\mathrm{av}}$ of the 90th with respect to the first pulse.

Furthermore, it was also stated in the literature that the electric-field strength and temperature level play a critical role during the IRE treatment $[8,20,27]$. Specifically, a larger electric-field strength (for $\mathrm{E}>\mathrm{E}_{\mathrm{IRE}(\mathrm{th})}$ ) results in a larger ablation area $[1,8,27]$, and temperature levels above a certain threshold would result in instantaneous thermal damage [8,9]. These facts were also observed in Figure 10, in which the exposure to $46^{\circ} \mathrm{C}$ resulted in thermal ablation of $15 \%$ of the cell suspension, while the increase of the electric-field strength from $500 \mathrm{~V} \cdot \mathrm{cm}^{-1}$ to $1250 \mathrm{~V} \cdot \mathrm{cm}^{-1}$ at $37^{\circ} \mathrm{C}$ resulted in an IPE ablation increase from $70 \%$ to $100 \%$. In addition, Figure 10 illustrated at $500 \mathrm{~V} \cdot \mathrm{cm}^{-1}$ that thermal elevation enhances the IPE ablation with additional $20 \%$ more cell death as a result. These data correspond with the data of Edelblute et al., which also showed that the enhancement of ablation increases with increasing temperature [27].

\subsection{HyCHEED Is Suitable for Investigation of Electroporation Treatment Modalities}

HyCHEED is suitable for investigating specific user-selected temperature levels on permeabilization during electroporation, such as in reversible, irreversible, and high-frequency irreversible electroporation (HF-IRE). This, to assess in more detail the possible contribution of thermal effects to the permeabilization effect (e.g., determine influence of elevated temperature levels on $\left.\mathrm{E}_{\mathrm{IRE}(\mathrm{th})}\right)$. Here, the temperature levels could be other than the $37^{\circ} \mathrm{C}$ and $46^{\circ} \mathrm{C}$ used in this paper. Due to the high-frequency electric current of HF-IRE, the demi-water can become lossy, thus lowering its impedance [42,43]. As a consequence, part of the high-frequency electric current would flow through the demi-water, possibly resulting in deterioration of the treatment efficacy. Still, for this technique, commercially available low viscous silicone oil can be used instead of demi-water to maintain the treatment efficacy, due to its lossless properties.

For the electroporation modalities, HyCHEED provides a temperature-controlled environment, in which the direct effect of a reasonably homogeneously distributed electric-field strength on electroporation can be determined. This can be done on several tissue types at user-defined temperature levels with limited temperature fluctuations. By determining the electrical properties as a function of electric-field strength and temperature of, e.g., human ex vivo tissues, we could apply this knowledge to improve the modeling of the electrical properties as used in numerical treatment planning for 
preparation, evaluation and optimization of the electroporation treatments $[44,45]$. In the numerical treatment planning of electroporation treatments, numerical calculations are performed on realistic $3 \mathrm{D}$ tumor models constructed from patient-specific medical images before the treatment. Here, the parameters of pulses and electrodes, such as pulse voltage, electrode number, and configuration, are numerically optimized for each patient.

\subsection{HyCHEED Is Suitable for Investigation of Radio-Frequency Treatments}

Radio-frequency (RF) treatments are treatment modalities in which a target tissue is exposed to high-frequency electromagnetic waves with the aim to induce thermal elevation within the target tissue [3]. In case of mild temperature elevations $\left(\mathrm{T} \leq 45{ }^{\circ} \mathrm{C}\right)$, the $\mathrm{RF}$ treatments can be used to enhance the therapeutic effects of adjuvant treatment modalities, such as radiotherapy and chemotherapy [46,47]. For large temperature elevation $\left(T \geq 60^{\circ} \mathrm{C}\right)$, the $\mathrm{RF}$ treatments are used as thermal ablation modalities, such as in radio-frequency ablation [48]. Despite the purpose of inducing temperature elevations, several studies suggested that the non-thermal RF waves also affect the target tissue next to hyperthermia [49-51]. For instance, Ware et al. investigated the influence of $\mathrm{RF}$ waves on the physical parameters of the pancreatic cell lines in the range of $33-39^{\circ} \mathrm{C}$ and found changes in cell topography, morphology, motility, adhesion, and division as the result of exposure to RF waves [49]. Another example is a study performed by Wust et al. [51], in which preclinical treatments in human colon cancer cell lines were performed by comparing water bath heating with RF hyperthermia at $42{ }^{\circ} \mathrm{C}$. The authors found that RF hyperthermia significantly reduced proliferation and clonogenicity compared to water bath hyperthermia, suggesting additional effects of non-thermal RF. In such studies, HyCHEED can be used to investigate the influence of RF waves on cell suspensions for several temperature levels within a well-controlled small temperature range. As mentioned above, the demi-water can be replaced by commercially available low viscous silicone oil that is lossless to avoid its impedance of becoming lossy due to the high-frequency electric current induced by the RF treatments.

\subsection{Future Directions}

HyCHEED offers the opportunity to determine the influence and the contribution of various temperature levels on several bio-electromagnetic techniques and electromagnetic properties (e.g., electrical specific conductivity). However, it is important to notice that the materials are temperature dependent and, therefore, it is important to choose materials with appropriate service temperatures to avoid setup failure. We used materials suitable for the present temperature range of $37-46^{\circ} \mathrm{C}$. Furthermore, by designing custom plate electrodes, HyCHEED would also be suitable for the use of ex vivo or 3D agarose targets. The present HyCHEED system was designed for performing temperature-controlled IRE for a single cuvette, the hydraulic circuit could be redesigned to allow application of temperature-controlled IRE in multiple cuvettes in parallel, which can be helpful for accelerating research when testing different cell lines as often required in today's journal standards.

\section{Conclusions}

In this study, we presented a hydraulically controllable heat exchange electroporation device (HyCHEED) that is capable of successfully treating the target volume with various electroporation settings at stable pre-defined clinically relevant temperature levels. This provides an excellent basis for important preclinical experiments to assess the extent of the contribution of thermal effects to the IRE ablation zone and determine the therapeutic ratio between thermal damage and irreversible permeabilization effects.

Supplementary Materials: The following are available online at http://www.mdpi.com/1424-8220/20/21/6227/s1, Table S1: The post-treatment $\sigma_{\mathrm{av}}$ of the target volume including the ratios with respect to the post-treatment $\sigma_{\mathrm{av}}$ of the control at $37^{\circ} \mathrm{C}$, Table S2: A summary of $\sigma_{\mathrm{av}}$ obtained from the first and the 90th pulses including the ratios with respect to the $\sigma_{\mathrm{av}}$ of the first pulse. 
Author Contributions: Conceptualization, H.P.K., J.C., J.A.V., and P.A.; data curation, P.A.; formal analysis, P.A.; funding acquisition, J.C., M.G.B., and T.M.v.G.; investigation, H.P.K., J.C., and P.A.; methodology, H.P.K., H.M.R., J.C., J.S., P.A., and R.Z.; supervision, H.P.K., H.M.R., and J.C.; validation, P.A.; visualization, H.P.K., J.C., and P.A.; writing-original draft preparation, P.A.; writing—review and editing, A.L.O., E.v.V., H.P.K., H.M.R., J.C., J.S., J.A.V., K.P.v.L., M.G.B., N.A.P.F., P.A., R.Z., and T.M.v.G.; All authors have read and agreed to the published version of the manuscript.

Funding: This research was financially supported by the Dutch Cancer Society (grant UvA 2014-7244).

Acknowledgments: Authors would like to thank J.F. van Asperen, W. Baron, T.H.L. Pepping, C.A. Schouten, P.J.C. Schepers and R. Tiggelaar for their technical support and M. IJff, L. Hartl, and R.F.C.P.A. Helderman for their support with the cell line cultivation.

Conflicts of Interest: Author(s) declared the following potential conflicts of interest with respect to the research, authorship, and/or publication of this article: K.P.v.L. and T.M.v.G. are paid consultants for Angio-Dynamics. Angio-Dynamics had no role in the design of the study; in the collection, analyses, or interpretation of data; in the writing of the manuscript, or in the decision to publish the results.

\section{Abbreviations and Definitions}

Abbreviations and
symbols of quantities
C-container
Demi-water
IRE
IPE

H-container

HF-IRE

HyCHEED

NA

Post-treatment $\sigma_{\mathrm{av}} \quad\left[\mathrm{S} \cdot \mathrm{m}^{-1}\right]$

T-holder

TV

E

$\mathbf{J}$

$\mathbf{J} \cdot \mathbf{E}$

$c_{p}$

d

$\mathrm{f}_{\mathrm{P}}$

$\mathrm{H}_{\mathrm{V}}$

$\mathrm{t}$

$t_{0}, t_{1}, \ldots, t_{5}$

$t_{\text {init }}$

$t_{P}$

$\sigma$

$\sigma_{\mathrm{av}}$

A

$\mathrm{E}=|\mathbf{E}|$

EIRE(th)
Unit

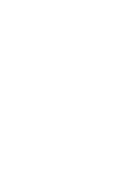

\section{Definition}

Container with demineralized water intended to cool off a target volume.

Demineralized water. Irreversible electroporation. Irreversible permeabilization effect (we chose IPE instead of IRE effect to distinguish between only the permeabilization effect, and the permeabilization and the thermal effects jointly produced by IRE).

Container with demineralized water intended to heat a target volume.

High-frequency irreversible electroporation.

Hydraulically controllable heat exchange electroporation device. Not applicable.

Average electrical specific conductivity of a target volume that is measured after the treatment.

Target holder.

Target volume.

Electric-field vector.

Electric-current density.

The Joule Heating term; the heat generation rate per unit volume. Specific heat capacity of a medium.

Distance between electrode plates of an electroporation cuvette.

Pulse frequency.

Volumetric heat transfer coefficient between the target volume and its direct ambiance.

Time.

Time points.

Initial time at which irreversible electroporation treatment starts.

Pulse duration.

Electrical specific conductivity of a target volume.

Average electrical specific conductivity of a target volume.

Surface of a target volume that is contacting the electrode plate of an electroporation cuvette.

Magnitude of an electric-field vector.

Electric-field threshold of irreversible electroporation; minimum electric-field value that ablates target cells/tissue during the irreversible electroporation.

Measured electric current. 


$\begin{array}{lll}\begin{array}{l}\text { Abbreviations and } \\ \text { symbols of quantities }\end{array} & \text { Unit } & \text { Definition } \\ \mathrm{SD} & & \\ \mathrm{T} & {\left[{ }^{\circ} \mathrm{C}\right]} & \text { Standard deviation. } \\ \mathrm{T}_{\text {target }} & {\left[{ }^{\circ} \mathrm{C}\right]} & \text { Temperature. } \\ \mathrm{T}_{\mathrm{A}} & {\left[{ }^{\circ} \mathrm{C}\right]} & \text { Target temperature. } \\ \mathrm{T}_{\mathrm{av}} & {\left[{ }^{\circ} \mathrm{C}\right]} & \text { Temperature of the direct ambient of the target volume. } \\ \Phi & {[\mathrm{V}]} & \text { Average temperature evolution over time. } \\ & & \text { Measured voltage. }\end{array}$

\section{Appendix A -Mathematical Description of Stable Temperature Control in Treated Volume}

The description of the thermal balance within a small target volume (TV; $300 \mu \mathrm{L}$ of cell suspension) that is presented as a purple cuboid in Figure 1 is based on the heat transfer equation

$$
\rho c_{\mathrm{p}} \frac{\partial \mathrm{T}}{\partial \mathrm{t}}=-\mathrm{H}_{\mathrm{V}} \cdot\left(\mathrm{T}-\mathrm{T}_{\mathrm{A}}\right)+\mathbf{J} \cdot \mathbf{E} \cdot \mathrm{t}_{\mathrm{P}} \cdot \mathrm{f}_{\mathrm{P}}
$$

where $\rho\left[\mathrm{kg} \cdot \mathrm{m}^{-3}\right]$ is the mass density, $\mathrm{c}_{\mathrm{p}}\left[\mathrm{J} \cdot \mathrm{kg}^{-1} \cdot{ }^{\circ} \mathrm{C}^{-1}\right]$ is the specific heat capacity, $\mathrm{T}\left[{ }^{\circ} \mathrm{C}\right]$ is the temperature, $\mathrm{t}[\mathrm{s}]$ is the time, and $\mathbf{J} \cdot \mathbf{E} \cdot \mathrm{t}_{\mathrm{P}} \cdot \mathrm{f}_{\mathrm{P}}\left[\mathrm{W} \cdot \mathrm{m}^{-3}\right]$ is the scaled heat generation rate per unit volume (the joule-heating term; $\mathbf{J} \cdot \mathbf{E}$ $\left[\mathrm{W} \cdot \mathrm{m}^{-3}\right]$ ) over the period $1 / \mathrm{f}_{\mathrm{P}}[\mathrm{s}]$, with $\mathbf{J}\left[\mathrm{A} \cdot \mathrm{m}^{-2}\right]$ as the electric-current density, $\mathrm{E}\left[\mathrm{V} \cdot \mathrm{m}^{-1}\right]$ as the electric field, $\mathrm{t}_{\mathrm{P}}$ [s] as the pulse duration, and $\mathrm{f}_{\mathrm{P}}[\mathrm{Hz}]$ as the pulse frequency [20]. The term $\mathrm{H}_{\mathrm{V}} \cdot\left(\mathrm{T}-\mathrm{T}_{\mathrm{A}}\right)$ represents the rate of heat flow into the TV and is utilized when, e.g., thermal advection is applied through water flow surrounding the TV. Here, $\mathrm{H}_{\mathrm{V}}\left[\mathrm{W} \cdot \mathrm{m}^{-3} \cdot{ }^{\circ} \mathrm{C}^{-1}\right]$ is the volumetric heat transfer coefficient between the TV and its direct ambiance with the temperature $\mathrm{T}_{\mathrm{A}}\left[{ }^{\circ} \mathrm{C}\right]$. This term is used to heat the $\mathrm{TV}$, as was shown in Figure $1 \mathrm{~A}$ (the term is represented by orange arrows), or to cool it down, as in Figure $1 \mathrm{C}$ (the term is represented by blue arrows). Since we only apply IRE pulses in this study, the joule-heating term can have the form

$$
\mathbf{J} \cdot \mathbf{E}=\sigma \cdot \mathbf{E}^{2}
$$

with $\sigma\left[\mathrm{S} \cdot \mathrm{m}^{-1}\right]$ as the electrical specific conductivity of the TV, and $\mathrm{E}\left[\mathrm{V} \cdot \mathrm{m}^{-1}\right]$ as the magnitude of the electric field (other term is the electric-field strength) to which the TV is exposed [20]. An example of electric pulses are shown in Figure $1 \mathrm{~B}$ with $\mathrm{t}_{\text {init }}[\mathrm{s}]$ as the initial time at which the electric pulses are applied.

To maintain a stable temperature in the TV at the target temperature $\left(\mathrm{T}_{\text {target }}\left[{ }^{\circ} \mathrm{C}\right]\right.$; desired temperature at which electroporation is applied), the temporal temperature change must satisfy

$$
\frac{\partial \mathrm{T}}{\partial \mathrm{t}}=0
$$

resulting in two distinct scenes:

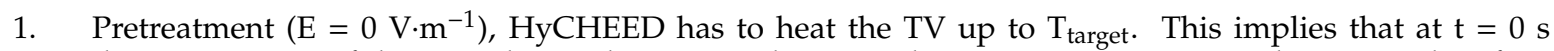
the temperature of the TV is lower than $\mathrm{T}_{\mathrm{A}}$, and in time the temperature must reach $\mathrm{T}_{\text {target. Therefore, }}$ $\mathrm{T}_{\mathrm{A}}=\mathrm{T}_{\text {target}}$. See Figure 1A.

2. During the treatment $\left(\mathrm{E}>0 \mathrm{~V} \cdot \mathrm{m}^{-1}\right)$, a stable temperature is maintained when the temperature rise caused purely by the electric pulses (Figure $1 \mathrm{~B}$ ) is combined with the temperature decrease caused solely by the cooling effect of term $\mathrm{H}_{\mathrm{V}} \cdot\left(\mathrm{T}-\mathrm{T}_{\mathrm{A}}\right.$ ) (Figure $1 \mathrm{C}$ ) to obtain a steady temperature as in Figure 1D. To satisfy this condition, $\mathrm{T}_{\mathrm{A}}$ must be adjusted at $\mathrm{t}=\mathrm{t}_{\text {init }}$ such that $\mathrm{T}_{\mathrm{A}}<\mathrm{T}_{\text {target }}$. Using the combination of Equations (A1) and (A3), we can calculate $\mathrm{T}_{\mathrm{A}}$ by reducing Equation (A1) into

$$
\sigma \cdot E^{2} \cdot t_{P} \cdot f_{P}=H_{V} \cdot\left(T-T_{A}\right)
$$

resulting in the steady state solution

$$
\mathrm{T}=\mathrm{T}_{\mathrm{A}}+\frac{\sigma \cdot \mathrm{E}^{2} \cdot \mathrm{t}_{\mathrm{P}} \cdot \mathrm{f}_{\mathrm{P}}}{\mathrm{H}_{\mathrm{V}}}
$$

or

$$
\mathrm{T}_{\text {target }}=\mathrm{T}_{\mathrm{A}}+\frac{\sigma \cdot \mathrm{E}^{2} \cdot \mathrm{t}_{\mathrm{P}} \cdot \mathrm{f}_{\mathrm{P}}}{\mathrm{H}_{\mathrm{V}}}
$$




\section{References}

1. Davalos, R.V.; Mir, L.M.; Rubinsky, B. Tissue ablation with irreversible electroporation. Ann. Biomed. Eng. 2005, 33, 223-231. [CrossRef] [PubMed]

2. Geboers, B.; Scheffer, H.J.; Graybill, P.M.; Ruarus, A.H.; Nieuwenhuizen, S.; Puijk, R.S.; van den Tol, P.M.; Davalos, R.V.; Rubinsky, B.; de Gruijl, T.D.; et al. High-Voltage Electrical Pulses in Oncology: Irreversible Electroporation, Electrochemotherapy, Gene Electrotransfer, Electrofusion, and Electroimmunotherapy. Radiology 2020, 295, 254-272. [CrossRef] [PubMed]

3. Kok, H.P.; Cressman, E.N.K.; Ceelen, W.; Brace, C.L.; Ivkov, R.; Grüll, H.; Ter Haar, G.; Wust, P.; Crezee, J. Heating technology for malignant tumors: A review. Int. J. Hyperth. 2020, 37, 711-741. [CrossRef] [PubMed]

4. Neal, R.E.; Garcia, P.A.; Robertson, J.L.; Davalos, R.V. Experimental Characterization and Numerical Modeling of Tissue Electrical Conductivity during Pulsed Electric Fields for Irreversible Electroporation Treatment Planning. IEEE Trans. Biomed. Eng. 2012, 59, 1076-1085. [CrossRef]

5. Mercadal, B.; Beitel-White, N.; Aycock, K.N.; Castellvi, Q.; Davalos, R.V.; Ivorra, A. Dynamics of Cell Death After Conventional IRE and H-FIRE Treatments. Ann. Biomed. Eng. 2020, 1-12. [CrossRef] [PubMed]

6. Vogel, J.A.; van Veldhuisen, E.; Agnass, P.; Crezee, J.; Dijk, F.; Verheij, J.; van Gunk, T.M.; Meijerink, M.R.; Vroomen, L.G.; van Lienden, K.P.; et al. Time-Dependent Impact of Irreversible Electroporation on Pancreas, Liver, Blood Vessels and Nerves: A Systematic Review of Experimental Studies. PLoS ONE 2016, 11, e0166987. [CrossRef] [PubMed]

7. Pillai, K.; Akhter, J.; Chua, T.C.; Shehata, M.; Alzahrani, N.; Al-Alem, I.; Morris, D.L. Heat Sink Effect on Tumor Ablation Characteristics as Observed in Monopolar Radiofrequency, Bipolar Radiofrequency, and Microwave, Using Ex Vivo Calf Liver Model. Medicine 2015, 94. [CrossRef]

8. Faroja, M.; Ahmed, M.; Appelbaum, L.; Ben-David, E.; Moussa, M.; Sosna, J.; Nissenbaum, I.; Goldberg, S.N. Irreversible Electroporation Ablation: Is All the Damage Nonthermal? Radiology 2013, 266, 462-470. [CrossRef]

9. Dunki-Jacobs, E.M.; Philips, P.; Martin, R.C.G. Evaluation of thermal injury to liver, pancreas and kidney during irreversible electroporation in an in vivo experimental model. Br. J. Surg. 2014, 101, 1113-1121. [CrossRef]

10. Wagstaff, P.G.K.; de Bruin, D.M.; van den Bos, W.; Ingels, A.; van Gemert, M.J.C.; Zondervan, P.J.; Verdaasdonk, R.M.; van Lienden, K.P.; van Leeuwen, T.G.; de la Rosette, J.; et al. Irreversible electroporation of the porcine kidney: Temperature development and distribution. Urol. Oncol. Semin. Orig. Investig. 2015, 33. [CrossRef]

11. Agnass, P.; van Veldhuisen, E.; Vogel, J.A.; Kok, H.P.; de Keijzer, M.J.; Schooneveldt, G.; de Haan, L.R.; Klaessens, J.H.; Scheffer, H.J.; Meijerink, M.R.; et al. Thermodynamic profiling during irreversible electroporation in porcine liver and pancreas: A case study series. J. Clin. Transl. Res. 2020, 5, 109-132. [CrossRef]

12. Bakker, A.; van der Zee, J.; van Tienhoven, G.; Kok, H.P.; Rasch, C.R.N.; Crezee, H. Temperature and thermal dose during radiotherapy and hyperthermia for recurrent breast cancer are related to clinical outcome and thermal toxicity: A systematic review. Int. J. Hyperth. 2019, 36, 1024-1039. [CrossRef] [PubMed]

13. Kroesen, M.; Mulder, H.T.; van Holthe, J.M.L.; Aangeenbrug, A.A.; Mens, J.W.M.; van Doorn, H.C.; Paulides, M.M.; Oomen-de Hoop, E.; Vernhout, R.M.; Lutgens, L.C.; et al. Confirmation of thermal dose as a predictor of local control in cervical carcinoma patients treated with state-of-the-art radiation therapy and hyperthermia. Radiother. Oncol. 2019, 140, 150-158. [CrossRef] [PubMed]

14. Helderman, R.F.C.P.A.; Loke, D.R.; Kok, H.P.; Oei, A.L.; Tanis, P.J.; Franken, N.A.P.K.; Crezee, J. Variation in Clinical Application of Hyperthermic Intraperitoneal Chemotherapy: A Review. Cancers 2019, 11, 78. [CrossRef] [PubMed]

15. Oei, A.L.; Kok, H.P.; Oei, S.B.; Horsman, M.R.; Stalpers, L.J.A.; Franken, N.A.P.; Crezee, J. Molecular and biological rationale of hyperthermia as radio- and chemosensitizer. Adv. Drug Deliv. Rev. 2020. [CrossRef]

16. Hildebrandt, B.; Wust, P.; Ahlers, O.; Dieing, A.; Sreenivasa, G.; Kerner, T.; Felix, R.; Riess, H. The cellular and molecular basis of hyperthermia. Crit. Rev. Oncol./Hematol. 2002, 43, 33-56. [CrossRef]

17. Bull, J.M.C. A review of immune therapy in cancer and a question: Can thermal therapy increase tumor response? Int. J. Hyperth. 2018, 34, 840-852. [CrossRef] 
18. Gerweck, L.E. Hyperthermia in Cancer Therapy: The Biological Basis and Unresolved Questions. Cancer Res. 1985, 45, 3408-3414.

19. Horsman, M.R. Tissue physiology and the response to heat. Int. J. Hyperth. 2006, 22, 197-203. [CrossRef]

20. Agnass, P.; van Veldhuisen, E.; van Gemert, M.J.C.; van der Geld, C.W.M.; van Lienden, K.P.; van Gulik, T.M.; Meijerink, M.R.; Besselink, M.G.; Kok, H.P.; Crezee, J. Mathematical modeling of the thermal effects of irreversible electroporation for in vitro, in vivo, and clinical use: A systematic review. Int. J. Hyperth. 2020, 37, 486-505. [CrossRef]

21. Dewhirst, M.W.; Viglianti, B.L.; Lora-Michiels, M.; Hanson, M.; Hoopes, P.J. Basic principles of thermal dosimetry and thermal thresholds for tissue damage from hyperthermia. Int. J. Hyperth. 2003, 19, $267-294$. [CrossRef] [PubMed]

22. Gordon, R.T.; Hines, J.R.; Gordon, D. Intracellular hyperthermia: A biophysical approach to cancer treatment via intracellular temperature and biophysical alterations. Med. Hypotheses 1979, 5, 83-102. [CrossRef]

23. Ivkov, R. Magnetic nanoparticle hyperthermia: A new frontier in biology and medicine? Int. J. Hyperth. 2013, 29, 703-705. [CrossRef] [PubMed]

24. Raaijmakers, E.A.L.; Mestrom, R.M.C.; Sumser, K.; Salim, G.; Rhoon, G.C.; Essers, J.; Paulides, M.M. An MR-compatible antenna and application in a murine superficial hyperthermia applicator. Int. J. Hyperth. 2018, 34, 697-703. [CrossRef]

25. Crezee, J.; Tienhoven, G.v.; Kolff, M.W.; Sijbrands, J.; Stam, G.v.; Oldenborg, S.; Geysen, E.D.; Hulshof, M.C.C.M.; Kok, H.P. Development of a $70 \mathrm{MHz}$ unit for hyperthermia treatment of deep seated breast tumors. In Proceedings of the 2016 46th European Microwave Conference (EuMC), London, UK, 4-6 October 2016; pp. 906-909.

26. Zhu, L.F.; Altman, M.B.; Laszlo, A.; Straube, W.; Zoberi, I.; Hallahan, D.E.; Chen, H. Ultrasound Hyperthermia Technology for Radiosensitization. Ultrasound Med. Biol. 2019, 45, 1025-1043. [CrossRef] [PubMed]

27. Edelblute, C.M.; Hornef, J.; Burcus, N.I.; Norman, T.; Beebe, S.J.; Schoenbach, K.; Heller, R.; Jiang, C.Q.; Guo, S.Q. Controllable Moderate Heating Enhances the Therapeutic Efficacy of Irreversible Electroporation for Pancreatic Cancer. Sci. Rep. 2017, 7. [CrossRef]

28. Zhang, B.; Yang, Y.J.; Ding, L.J.; Moser, M.A.J.; Zhang, E.M.; Zhang, W.J. Tumor Ablation Enhancement by Combining Radiofrequency Ablation and Irreversible Electroporation: An In Vitro 3D Tumor Study. Ann. Biomed. Eng. 2019, 47, 694-705. [CrossRef] [PubMed]

29. Vogel, J.A.; Rombouts, S.J.; de Rooij, T.; van Delden, O.M.; Dijkgraaf, M.G.; van Gulik, T.M.; van Hooft, J.E.; van Laarhoven, H.W.; Martin, R.C.; Schoorlemmer, A.; et al. Induction Chemotherapy Followed by Resection or Irreversible Electroporation in Locally Advanced Pancreatic Cancer (IMPALA): A Prospective Cohort Study. Ann. Surg. Oncol. 2017, 24, 2734-2743. [CrossRef]

30. Timmer, F.E.F.; Geboers, B.; Ruarus, A.H.; Schouten, E.A.C.; Nieuwenhuizen, S.; Puijk, R.S.; de Vries, J.J.J.; Meijerink, M.R.; Scheffer, H.J. Irreversible Electroporation for Locally Advanced Pancreatic Cancer. Tech. Vasc. Interv. Radiol. 2020, 23, 443-449. [CrossRef]

31. Ruarus, A.H.; Vroomen, L.; Geboers, B.; van Veldhuisen, E.; Puijk, R.S.; Nieuwenhuizen, S.; Besselink, M.G.; Zonderhuis, B.M.; Kazemier, G.; de Gruijl, T.D.; et al. Percutaneous Irreversible Electroporation in Locally Advanced and Recurrent Pancreatic Cancer (PANFIRE-2): A Multicenter, Prospective, Single-Arm, Phase II Study. Radiology 2020, 294, 212-220. [CrossRef]

32. Garcia, P.A.; Arena, C.B.; Davalos, R.V. Towards a predictive model of electroporation-based therapies using pre-pulse electrical measurements. In Proceedings of the 2012 Annual International Conference of the IEEE Engineering in Medicine and Biology Society, San Diego, CA, USA, 28 August-1 September 2012; Volume 2012, pp. 2575-2578. [CrossRef]

33. Xu, M.L.; McCanna, D.J.; Sivak, J.G. Use of the viability reagent PrestoBlue in comparison with alamarBlue and MTT to assess the viability of human corneal epithelial cells. J. Pharmacol. Toxicol. Methods 2015, 71, 1-7. [CrossRef] [PubMed]

34. Napotnik, T.B.; Miklavcic, D. In vitro electroporation detection methods-An overview. Bioelectrochemistry 2018, 120, 166-182. [CrossRef] [PubMed]

35. Piccinini, F.; Tesei, A.; Arienti, C.; Bevilacqua, A. Cell Counting and Viability Assessment of 2D and 3D Cell Cultures: Expected Reliability of the Trypan Blue Assay. Biol. Proced. Online 2017, 19. [CrossRef] 
36. Chang, A.-Y.; Liu, X.; Tian, H.; Hua, L.; Yang, Z.; Wang, S. Microfluidic Electroporation Coupling Pulses of Nanoseconds and Milliseconds to Facilitate Rapid Uptake and Enhanced Expression of DNA in Cell Therapy. Sci. Rep. 2020, 10, 6061. [CrossRef]

37. Sel, D.; Cukjati, D.; Batiuskaite, D.; Slivnik, T.; Mir, L.M.; Miklavcic, D. Sequential finite element model of tissue electropermeabilization. IEEE Trans. Biomed. Eng. 2005, 52, 816-827. [CrossRef] [PubMed]

38. Rems, L.; Miklavcic, D. Tutorial: Electroporation of cells in complex materials and tissue. J. Appl. Phys. 2016, 119. [CrossRef]

39. Ivorra, A.; Rubinsky, B. In vivo electrical impedance measurements during and after electroporation of rat liver. Bioelectrochemistry 2007, 70, 287-295. [CrossRef]

40. Ivorra, A.; Al-Sakere, B.; Rubinsky, B.; Mir, L.M. In vivo electrical conductivity measurements during and after tumor electroporation: Conductivity changes reflect the treatment outcome. Phys. Med. Biol. 2009, 54, 5949-5963. [CrossRef]

41. Langus, J.; Kranjc, M.; Kos, B.; Sustar, T.; Miklavcic, D. Dynamic finite-element model for efficient modelling of electric currents in electroporated tissue. Sci. Rep. 2016, 6. [CrossRef]

42. Hasgall, P.A.; Di Gennaro, F.; Baumgartner, C.; Neufeld, E.; Lloyd, B.; Gosselin, M.C.; Payne, D.; Klingenböck, A.; Kuster, N. IT'IS Database for Thermal and Electromagnetic Parameters of Biological Tissues. Available online: https://itis.swiss/virtual-population/tissue-properties/database/database-summary/ (accessed on 15 May 2018).

43. Paulides, M.M.; Vossen, S.; Zwamborn, A.P.M.; Van Rhoon, G.C. Theoretical investigation into the feasibility to deposit RF energy centrally in the head-and-neck region. Int. J. Radiat. Oncol. Biol. Phys. 2005, 63, 634-642. [CrossRef]

44. Kos, B.; Voigt, P.; Miklavcic, D.; Moche, M. Careful treatment planning enables safe ablation of liver tumors adjacent to major blood vessels by percutaneous irreversible electroporation (IRE). Radiol. Oncol. 2015, 49, 234-241. [CrossRef]

45. Zupanic, A.; Kos, B.; Miklavcic, D. Treatment planning of electroporation-based medical interventions: Electrochemotherapy, gene electrotransfer and irreversible electroporation. Phys. Med. Biol. 2012, 57, 5425-5440. [CrossRef]

46. Van der Zee, J.; Gonzalez, D.G.; van Rhoon, G.C.; van Dijk, J.D.P.; van Putten, W.L.J.; Hart, A.A.M. Comparison of radiotherapy alone with radiotherapy plus hyperthermia in locally advanced pelvic tumours: A prospective, randomised, multicentre trial. Lancet 2000, 355, 1119-1125. [CrossRef]

47. Cho, C.H.; Wust, P.; Hildebrandt, B.; Issels, R.D.; Sehouli, J.; Kerner, T.; Deja, M.; Budach, V.; Gellermann, J. Regional hyperthermia of the abdomen in conjunction with chemotherapy for peritoneal carcinomatosis: Evaluation of two annular-phased-array applicators. Int. J. Hyperth. 2008, 24, 399-408. [CrossRef] [PubMed]

48. Izzo, F.; Granata, V.; Grassi, R.; Fusco, R.; Palaia, R.; Delrio, P.; Carrafiello, G.; Azoulay, D.; Petrillo, A.; Curley, S.A. Radiofrequency Ablation and Microwave Ablation in Liver Tumors: An Update. Oncologist 2019, 24, E990-E1005. [CrossRef]

49. Ware, M.J.; Tinger, S.; Colbert, K.L.; Corr, S.J.; Rees, P.; Koshkina, N.; Curley, S.; Summers, H.D.; Godin, B. Radiofrequency treatment alters cancer cell phenotype. Sci. Rep. 2015, 5. [CrossRef]

50. Curley, S.A.; Palalon, F.; Lu, X.L.; Koshkina, N.V. Noninvasive Radiofrequency Treatment Effect on Mitochondria in Pancreatic Cancer Cells. Cancer 2014, 120, 3418-3425. [CrossRef]

51. Wust, P.; Kortum, B.; Strauss, U.; Nadobny, J.; Zschaeck, S.; Beck, M.; Stein, U.; Ghadjar, P. Non-thermal effects of radiofrequency electromagnetic fields. Sci. Rep. 2020, 10. [CrossRef]

Publisher's Note: MDPI stays neutral with regard to jurisdictional claims in published maps and institutional affiliations.

(C) 2020 by the authors. Licensee MDPI, Basel, Switzerland. This article is an open access article distributed under the terms and conditions of the Creative Commons Attribution (CC BY) license (http://creativecommons.org/licenses/by/4.0/). 